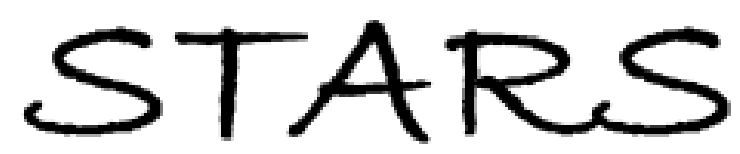

University of Central Florida

STARS

PRISM: Political \& Rights Issues \& Social Movements

$1-1-1962$

\title{
Population and food supply
}

United Nations Office of Public Information

Find similar works at: https://stars.library.ucf.edu/prism

University of Central Florida Libraries http://library.ucf.edu

This Book is brought to you for free and open access by STARS. It has been accepted for inclusion in PRISM: Political \& Rights Issues \& Social Movements by an authorized administrator of STARS. For more information, please contact STARS@ucf.edu.

\section{Recommended Citation}

United Nations Office of Public Information, "Population and food supply" (1962). PRISM: Political \& Rights Issues \& Social Movements. 508.

https://stars.library.ucf.edu/prism/508

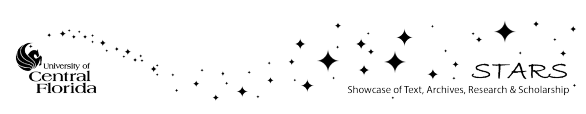


rreedom from Hunger Campaign

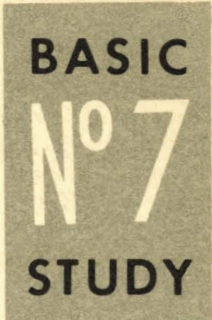

\section{POPULATION}

AND

\section{FOOD SUPPLY}

UNITED NATIONS 



\section{POPULATION \\ AND \\ FOOD SUPPLY}




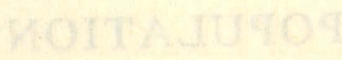

G1MA

X woly2 a60? 
Sales number: 62.I.22

Price: $\$ 0.50 ; 3 / 6$ sterling; 2.00 Swiss francs 


\section{Freedom From Hunger Campaign}

\section{Basic Studies Series}

A series of Basic Studies supporting the Freedom from Hunger Campaign is being published by the Food and Agriculture Organization and other organizations of the United Nations.

Sixteen such studies are contemplated in the series; nine will be issued by the Food and Agriculture Organization (FAO), three by the United Nations, and one each by the United Nations Educational, Scientific and Cultural Organization (UNESCO), the International Labour Organisation (ILO), the World Health Organization (wHO) and the World Meteorological Organization (WMO).

The subjects cover a wide range and include, for example, the possibilities of increasing world food production, the part marketing can play in increasing productivity, education and training in nutrition, animal diseases and human health, economic development through food, population and food supplies, education in relation to agriculture and economic development, hunger and social policy, malnutrition and disease, weather and food.

This volume, Population and food supply, issued by the United Nations Office of Public Information, is No. 7 in the series.

The following titles have already been issued:

No. 1: Weather and food; Le temps et la production alimentaire; El tiempo y la alimentación; published by WMO, Geneva.

No. 2: Development through food-a strategy for surplus utilization; Les produits alimentaires au service du progrès; El desarrollo económico mediante productos alimenticios-un plan estratégico para el empleo de excedentes; published by FAO, Rome.

No. 3: Animal disease and human health; Les maladies animales et la santé humaine; Las enfermedades de los animales y la salud humana; published by FAO, Rome.

Copies of the volumes in this series are obtainable directly from the respective issuing organization or its sales agents. 
This report has been prepared for the United Nations as a contribution of factual material for the Freedom from Hunger Campaign sponsored by the Food and Agriculture Organization of the United Nations.

The report was prepared by Mr. Robert C. Cook, President of the Population Reference Bureau, Inc. The views stated in the report are those of the author and not necessarily those of the United Nations. 


\section{Contents}

Preface

ix

Foreword

xi

Introduction . . . . . . . . . . . . . . . . . . xiii

I. Recent Trends in World Population . . . . . . . . 1

Regional classification of populations . . . . . . . . 3

II. Food Needs in Relation to Population Growth

in Various Regions . . . . . . . . . . . . . 10

Population Predictions . . . . . . . . . . . . . 11

Relation of demographic trends to social and economic factors 16

III. Cities and Food . . . . . . . . . . . . . . . . 19

How urbanization affects food supplies . . . . . . 20

IV. Present Food Supplies and Estimated Future Requirements . 22

Present food deficits . . . . . . . . . . . . 22

Trends in demand for foodstuffs . . . . . . . . . . 25

Population growth and food requirements . . . . . . . 28

Prospects for increasing food production . . . . . . . 31

V. Means of Increasing Output of Food . . . . . . . . 34

Summary of the problem of food production . . . . . 41

VI. The Issue of Population Policy

Prospects of increasing food production . . . . . . 48 


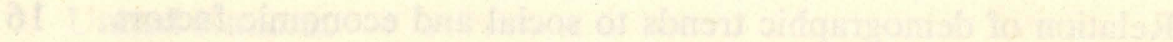

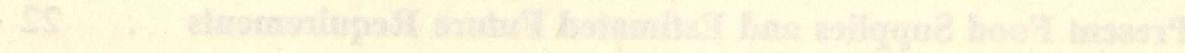




\section{Preface}

On the occasion of the inauguration of the Freedom from Hunger Campaign, the Secretary-General of the United Nations welcomed the initiative taken by the Food and Agriculture Organization and its DirectorGeneral "to center world attention and to speed action, both national and international, on the continuing problem of hunger and malnutrition" and pledged the vigorous and enthusiastic support of the United Nations toward the achievement of the goals of the Campaign. As one of the facets of this support, the Secretary-General agreed that the United Nations would prepare and issue three pamphlets dealing with some of the more general implications of the Campaign. The present pamphlet on "Population and Food Supply" is accompanied by two others-on "Aspects of Economic Development" and on "National Development Efforts."

Since the inauguration of the Freedom from Hunger Campaign, the General Assembly of the United Nations has decided to designate the current decade as the United Nations Development Decade in which all member governments and their peoples, as well as the United Nations family of organizations, would intensify their efforts for the economic and social advancement of the under-developed countries. Noting the close relationship between the objectives of the two campaigns, the Director-General of the FAO recently proposed, and the Secretary-General of the United Nations wholeheartedly agreed, that the Freedom from Hunger Campaign, should be an important part of the United Nations Development Decade. It is, therefore, hoped that the three pamphlets prepared by the United Nations for the Freedom from Hunger Campaign will contribute to a better understanding of the close relationship between the problems of population growth and economic development on the one hand and freedom from hunger on the other within the broader context of the Development Decade. 


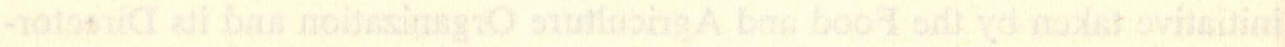

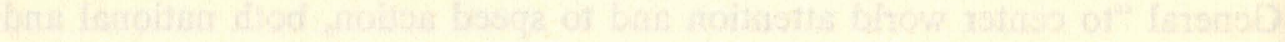

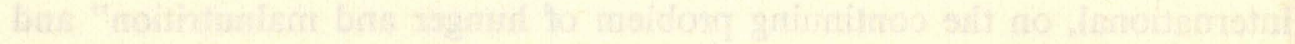

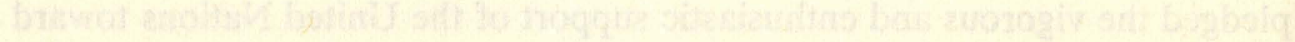

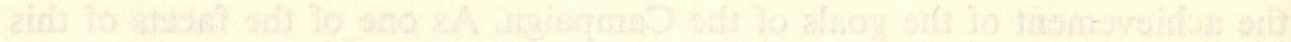

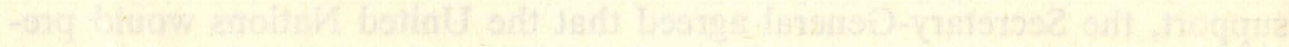

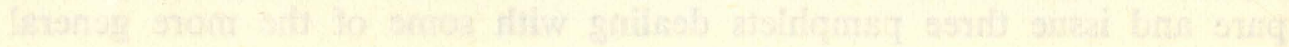

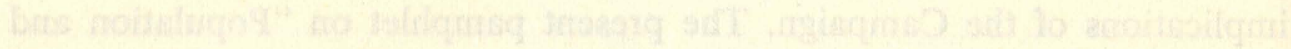

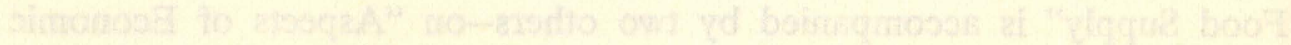

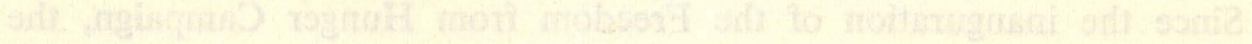

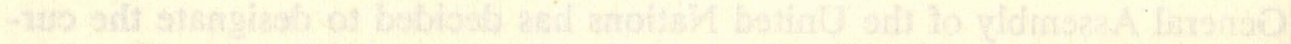

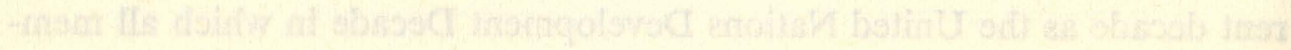

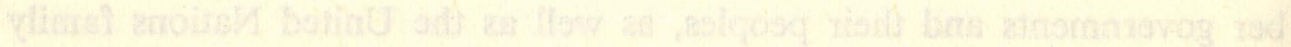

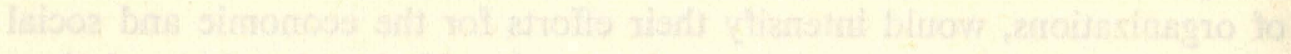

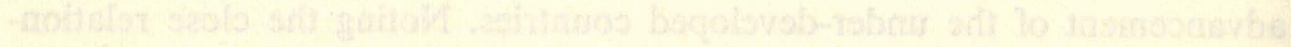

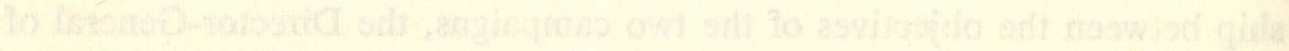

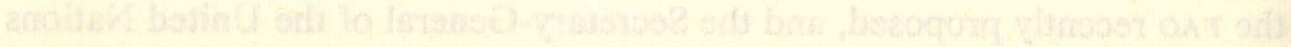

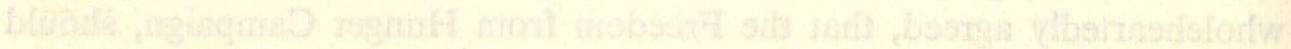

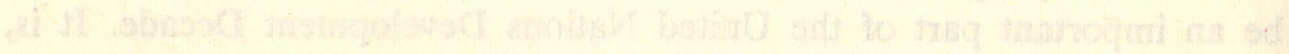

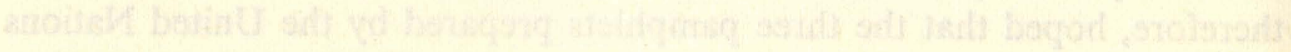

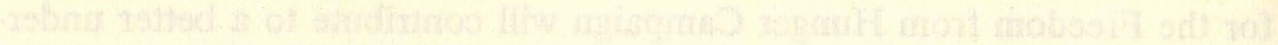

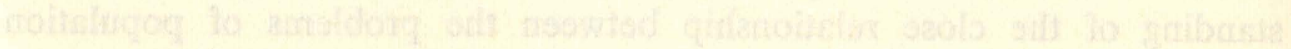

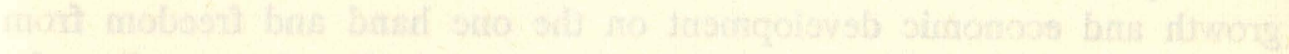

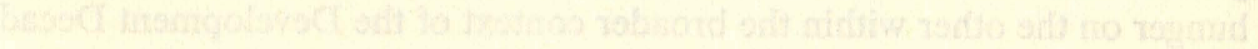




\section{Foreword}

The first half of the twentieth century has witnessed three major revolutions. The political revolution has given self-government to nearly a third of the world's population and has brought their aspirations for a better life to the forefront of world attention. The revolution in communications has broken down the barriers of distance and language, and the dynamism of ideas can no longer be contained within the limits dictated by social privilege or political considerations. The demographic revolution has imparted to the challenge of poverty and want a new dimension.

It is against this background that the Freedom from Hunger Campaign was launched in 1960 by the Food and Agriculture Organization of the United Nations. Its main objectives are twofold: first, to create a worldwide awareness of the problems of hunger and malnutrition which afflict more than a half of the world's population and which, apart from the human suffering and human degradation that they involve, pose a serious threat to peace and orderly progress, and second, to promote a climate of opinion in which solutions to these problems can be organized both on a national and on an international basis.

In the short time since its launching, the Campaign has already provided a focus for co-operative endeavor for international organizations, national governments, nongovernmental organizations and various citizens' groups all over the world. The 104 Member Nations attending the biennial session of the FAo Conference in November 1961 paid unanimous tribute to the significance of this Campaign for the future well-being of the world.

The Freedom from Hunger Campaign attempts to attack the problem of hunger on a broad front and at all levels of economic and social thought and action; but for practical purposes, it defines three sectors of operation: (a) information and education, (b) research, and (c) action.

The information and education sector will help bring to citizens everywhere a living awareness of the concrete facts and issues, and provide bases for deciding what new national and international policies and action programs are needed. This effort to create informed and active awareness will 
rise to a climax with the World Food Congress to be held under FAO auspices in 1963. Many international professional and citizens' groups will hold forums on Campaign issues in 1962 and 1963. Many national Campaign Committees will also organize similar discussions. Representatives from all these bodies are expected to participate in the World Food Congress and help bring into focus policies and action plans for the future.

The series of Basic Studies has been prepared by FAO and other cooperating international organizations to aid citizens in discussing the great issues involved.

These documents attempt to summarize the known facts and agreed conclusions of experts in each special field, and thus provide useful and reliable background material for study groups and public discussions.

The volumes in this series cover broad subjects such as the adequacy of food levels in the world, the possibilities of producing more food, and the ways in which economic development and training in the newly developing countries can raise buying power and thus help hungry people to buy more food for themselves. They bring out the central importance of good nutrition for health and working efflciency, and study how people can learn to choose their foods better. They appraise the efforts being made in individual countries to raise food output, to increase jobs and incomes, and to train and educate people in ways to increase production and in better dietary habits. The volumes cover the relation of food production to climate and weather, the better distribution and marketing of food, and the use of available surpluses to relieve hunger and provide an incentive to economic and social development in the developing countries.

I trust that these Basic Studies will stimulate thought and action on the critical problem of hunger and contribute to an ever-expanding understanding of the related social, economic and technical issues.

\author{
B. R. SEN \\ Director-General
}

Food and Agriculture Organization of the United Nations 


\section{Introduction}

Freedom from hunger, as well as freedom from fear, want, and persecution, was recognized by the founders of the United Nations as a basic right which should be guaranteed to all peoples. Even before the organization of the United Nations in 1945, some of the members-to-be began to assemble in smaller groups to consider common problems affecting these basic freedoms. One important meeting was convened by President Roosevelt at Hot Springs, Virginia, in May 1943, to consider the question of the world's food supply. Out of this conference emerged the Food and Agriculture Organization, devoted to the noble purpose of raising levels of nutrition and standards of living throughout the world. The participating governments signed the establishing articles of agreement at the White House later that year and FAO became a specialized agency of the United Nations on 16 October 1945.

FAO is now in its sixteenth year of activity as a United Nations agency. It continuously surveys the food resources of the world, and sets up research and extension programmes to assuage the world's hunger. FAO surveys have provided the most extensive and realistic information available concerning the world's food resources. Its co-operative projects, in which many nations have taken part, have done much to stimulate the production of food, its preservation from predators, and its effective distribution around the world. Although the resources available to FAo have always been extremely limited in relation to the magnitude of the problem, remarkable progress has been made in the achievement of these objectives.

But today the need to increase food resources is a large and more pressing problem than ever. It is necessary to increase food production at an accelerating rate in order to feed a population which is growing, in the world as a whole, at a more rapid rate than ever before. Moreover, food consumption per capita must be raised in the large parts of the world where the present levels are too low for health, and the rapid growth of population makes this a much more difficult matter.

It now appears that the 1960's will be crucial in determining the patterns of both future world population growth and the increase and development of 
population-supporting resources, facilities and services. Never has the balance between production and reproduction been more important. The interrelated variables-social, economic, political-are exceedingly complex; the task of finding a solution is enormous, and a survey of the agronomic and demographic factors involved provides no basis for easy confidence.

The aim of the following report is to survey population changes which have occurred, and are continuing to occur, in various regions of the world, and to discuss the effect which these changes are likely to have on the availability of world food supplies. 


\section{Recent Trends}

\section{in World Population}

The problem of hunger itself is not new, but the present magnitude of the problem transcends all previous human experience.

Man has always been dependent to a varying extent on the fluctuating ecological balance between people and the basic resources available to feed them, and although the capacity of the land to support human life has been constantly increased by human invention, the balance between between sufficiency and famine remained precarious throughout the world for centuries, and remains precarious to this day in some regions.

As human invention and abilities grew, the population also grew, though not necessarily in proportion to the increase in capacity for food production. At times, in various parts of the world, population outgrew the resources available at the time to feed it, and depopulation, by famine, disease or war, was the inevitable result.

However, it is true to say that over the long span of man's tenure of this earth, a gradual upward trend in the human population curve is established. From a relatively rare creature over half a million years ago, man (or protoman) moved upward from tens or hundreds of thousands to tens and hundreds of millions by the beginning of the Christian era. For the time of Christ's birth, scholars very tentatively set the total world population in the neighborhood of $200-300$ million. This guess is probably as good as the assumption generally accepted that this number approximately doubled by the middle of the 17th Century to 500 million. The thousand million mark was reached about two centuries later-by 1850; and in the succeeding 110 years the 3,000 million mark has been reached.

The rapidity of the recent increase contrasts sharply with the slow growth of past ages. To grow from some time-shrouded "beginning" to a few millions seems to have taken hundreds or thousands of millennia. Ages passed before the 250 million mark was reached two thousand years ago. Sixteen centuries more before the population reached 500 million. Then suddenly, it doubled in only two and a half centuries, and again in one century. Now world population is increasing at a rate which would double the number in about forty years. And the end is not necessarily in sight, for certain populations number- 
ing many millions are now growing at such a rate that they would double in twenty-five years.

Since the early years of the 19th century, revolutionary developments have occurred in the methods of producing the necessities and amenities of life. New sources of power and new methods of transport have been developed, and progress in medical science is one of the factors which have led to a decline in mortality.

To attribute all the acceleration in population growth in the past 150 years to discoveries in mortality control would obviously be an exaggeration. Without revolutions in technology, agriculture and transportation, such multitudes could not have been supported. On the other hand, without the knowledge and the means to control epidemics, the modern super-cities would have been more deadly than the ancient cities ever were and the increases in population would have been slower. Some measure of the impact of mortality control is given by the fact that in a world which since the beginning of history has sustained terrible visitations of plague, cholera, small pox, and diphtheria, there has not been a major pandemic since 1919, when influenza is believed to have caused 25 million deaths around the world.

In other words, world and national population growth has shifted from a wave-like pattern of gains and losses to a steady rapid upward trend.

In consequence of these changes, a fertility rate which only a few generations ago was essential to mere survival, now results in a rapid multiplication of numbers, by reason of ever better control of mortality.

Through all of man's previous history only a fraction of all the babies born had grown to maturity; now, in the industrial countries of the West, only $5 \%$ die before adulthood. While six to eight children per woman were once necessary to maintain human numbers, today only a fraction over two children per woman are necessary to maintain a stable population in the industrial countries.

Among the Western nations which led the Industrial Revolution and the modern movement of mortality control, the decline of death rates was followed after a longer or shorter interval by a compensatory adjustment of birth rates. This so-called "demographic transition" has resulted in a moderation of population growth in the industrial countries. In non-industrial countries, on the other hand, the rapid decline in death rates in recent decades has not yet been balanced by a decline in birth rates.

Moderation in population growth-either actual or incipient-now extends over all Europe (including the USSR), Northern America, temperate South America, Japan and Australia. These regions contain about a quarter of the human race. Yet even in these areas, where the people generally have only a comparatively small number of children, the low rates of mortality now established mean that the population still grows at rates which appear exhuberant by comparison with those of earlier historical epochs. In the United 
States of America, for instance, the prevailing rate of approximately three children per woman is only about half what was considered a minimum in traditional frontier society. Yet even this quite modest rate of reproduction, as compared with a century ago, serves to increase the population at the rate of almost 50 per cent per generation.

In the countries of the world other than those mentioned above, relatively little control of fertility is exercised and families are large. With persistently high birth rates and declining death rates, population growth already at an unprecedentedly high level, still tends to accelerate in precisely those regions where such growth creates the most serious social and economic problems. The rates of natural increase at present exceed three per cent a year in many of the countries in the less developed regions-enough to double the population in twenty-five years or less. In a few countries the increase even approaches a rate of four per cent. As low death rates are extended over wider and wider areas, it appears likely that increases of more than three per cent a year will soon be the rule in the under-developed regions which contain two thirds of the earth's inhabitants.

The continuation of high fertility in the face of the reduction of mortality, particularly in the economically less advanced regions, is the crux of the population problem in the world today, and is an integral and essential factor in any realistic approach to the food outlook.

\section{Regional classification of populations}

The demographic, social and economic statistics available today are adequate to permit a classification of the regions of the earth and most of the nations. Even though such data are admittedly inadequate for certain parts of the world, it is possible to distinguish certain regional categories in the light of present conditions and future prospects.

With respect to density and degree of technological advance, four categories of regions may be distinguished:

1. Technologically developed, low-density regions - including North America, temperate South America, Australia, New Zealand and the Soviet Union.

2. Technologically developed, high density regions-including Europe and Japan.

3. Technologically underdeveloped, low-density regions - including Africa, parts of Central America, tropical South America, Southwest Asia and the Pacific Islands.

4. Technologically underdeveloped, high-density regions-including the Caribbean, central South Asia, southeast Asia and east Asia (except Japan).

Obviously, the countries within these groups still differ from each other in very important respects. The technological development of North America 
and temperate South America is very different. The situation in Barbados (with a population density of 1,300 per square mile) is very different from that in India.

Out of a total world population of 3,000 million in 1961 , the population in the technologically developed regions amounted to a little over 1,000 million. As regards the developed regions, about half the population lies in the high-density regions, and half in the low-density regions.

Of the 2,000 million people in the underdeveloped regions, about one quarter live in the low-density regions, and about three quarters live in the high-density regions.

There is a high degree of correlation between the vital indices of the industrialized countries in both groups and the indices of the unindustrialized countries. All the technologically developed countries have moderated their birth rates. In the low-density industrial countries, the birth rates tend to be somewhat higher than in the high density countries. But the contrast between the birth rates of the underdeveloped countries and the developed countries is very striking. Although many of the technologically underdeveloped countries have very inadequate vital statistics, the pattern of population growth is well enough established to leave no doubt that in practically all these countries the birth rate ranges upward from 30 per thousand. It should be noted that this is not necessarily the "official" birth rate reported by governments to the United Nations; in many cases, more realistic figures are derived from various estimates. At the present time, the economically underdeveloped areas-without respect to density of population-are experiencing no marked change in the birth rate.

With respect to death rates, a much more fluid situation exists. Certain countries of the world-and these again are the most highly developed technologically-have achieved an extremely low death rate through effective control of mortality-especially during the early years of life. Death rates ranging between eight and twelve per thousand are found in most of the industrial nations of the world. Such death rates mean that expectation of life at birth ranges from 60 to 70 or more years.

Other countries of the world are in transition from traditionally high death rates (30 or 40 per thousand or even more) to rates characteristic of the urban-industrial nations of the West. The downward trend has proceeded most rapidly in Latin America. It is extending across Africa and Asia.

In a few countries of the world-for example, in central Africa and in the more isolated parts of Asia-the traditionally high-death rates are still to be found. But the downward trend of the death rate is virtually a worldwide phenomenon. Combined with persistently high birth rates, it results in accelerating population growth.

During the 19th century, the nations of Europe and northern America made a transition from the traditional pattern of slow population growth with 
high birth rate approximately in balance with a high death rate to a new pattern of moderate population growth with much lower birth rates and much lower death rates. During this transition, which occurred gradually over a century and a half, there was a very rapid growth of population. In these

TAB LE 1

POPULATION PROJECTIONS TO THE YEAR 2000, FOR THE WORLD, CONTINENTS, AND REGIONS

(United Nations "High" projections, in millions)

\begin{tabular}{|c|c|c|c|c|}
\hline Area & 1950 & 1960 & 1970 & 2000 \\
\hline World Total.................... & 2,500 & 2,920 & 3,500 & 6,280 \\
\hline 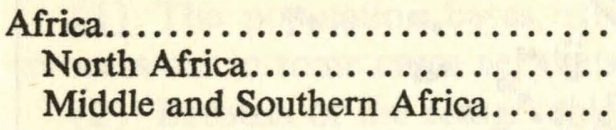 & $\begin{array}{r}199 \\
43 \\
156\end{array}$ & $\begin{array}{r}237 \\
53 \\
185\end{array}$ & $\begin{array}{r}294 \\
67 \\
227\end{array}$ & $\begin{array}{l}517 \\
147 \\
370\end{array}$ \\
\hline Northern America............... & 168 & 197 & 225 & 312 \\
\hline Latin America.................... & 163 & 206 & 265 & 592 \\
\hline $\begin{array}{l}\text { Asia (excluding the Asian part } \\
\text { of the Soviet Union and Japan).... }\end{array}$ & 1,296 & 1,524 & 1,870 & 3,717 \\
\hline Japan and Ryukyu Islands........... & 84 & 96 & 110 & 153 \\
\hline 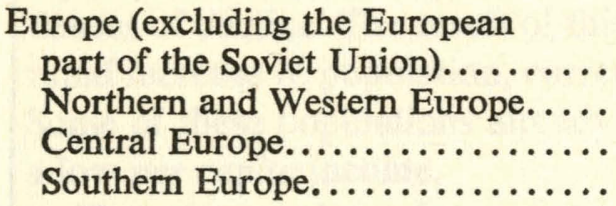 & $\begin{array}{l}393 \\
133 \\
128 \\
132\end{array}$ & $\begin{array}{l}424 \\
140 \\
140 \\
144\end{array}$ & $\begin{array}{l}457 \\
148 \\
151 \\
158\end{array}$ & $\begin{array}{l}568 \\
180 \\
183 \\
206\end{array}$ \\
\hline 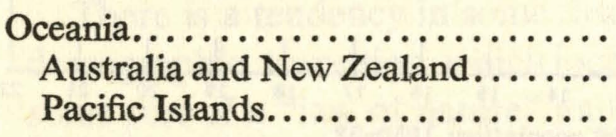 & $\begin{array}{r}13.2 \\
10.2 \\
2.9\end{array}$ & $\begin{array}{r}16.3 \\
12.7 \\
3.6\end{array}$ & $\begin{array}{r}19.4 \\
14.9 \\
4.5\end{array}$ & $\begin{array}{r}29.3 \\
20.8 \\
8.6\end{array}$ \\
\hline $\begin{array}{l}\text { Soviet Union (Asian and European } \\
\text { Parts Combined)................ }\end{array}$ & 181 & 215 & 254 & 379 \\
\hline
\end{tabular}

Source: The Future Growth of World Population (United Nations Publication, Sales No. 1958 XIII 2).

countries, the birth rate followed the death rate down after a lapse of a generation or so. Because of the lag in the decline of the birth rate, population growth was extremely rapid during the early years of the transition period. The birth rate began to decline when the people of these countries spontaneously began to limit their families to a relatively small number of children, by means of contraceptives and other forms of birth control. What caused them to do so is not completely understood. There has been much scholarly controversy concerning the dynamics of the cultural changes which unquestionably took place. It should be emphasized that the decline in the death 
DEATH RATES IN 76 COUNTRIES: 1950-52 AND 1953-55

(Rates are the average annual number of deaths per 1000 population.)

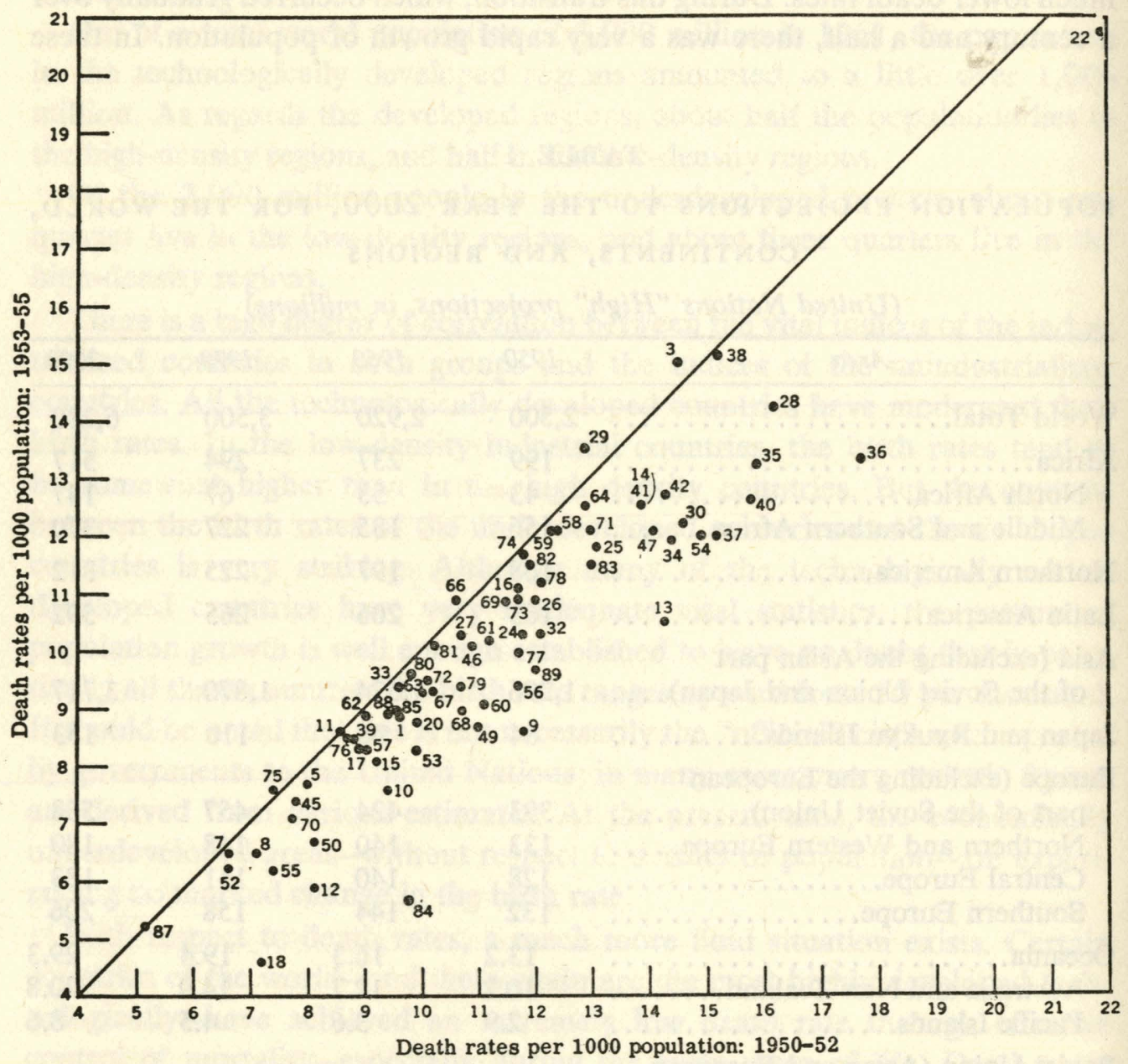

The countries below are identified by the following code:

$\begin{array}{ll}\text { 1. Algeria (European) } & \text { 23. Honduras } \\ \text { 2. Tunisia (European) } & \text { 24. Jamaica } \\ \text { 3. Mauritius } & \text { 25. Leeward Islands } \\ \text { 4. Rodrigues } & \text { 26. Antigua } \\ \text { 5. Morocco [former French Zone] (non-indigenous) } & \text { 27. Virgin Islands [UK] } \\ \text { 6. Mozambique (non-indigenous) } & \text { 28. Mexico } \\ \text { 7. Southern Rhodesia (European) } & \text { 29. Moeward Islands } \\ \text { 8. South West Africa (white) } & \text { 30. St. Kitts-Nevis and Anguilla } \\ \text { 9. Ceuta } & \text { 31. Puerto Rico } \\ \text { 10. Melilla } & \text { 32. Trinidad and Tobago } \\ \text { 11. Union of South Africa } & \text { 33. United States } \\ \text { 12. Alaska } & \text { 34. Virgin Islands [US] } \\ \text { 13. Bahama Islands } & \text { 35. Windward Islands } \\ \text { 14. Barbados } & \text { 36. Dominica } \\ \text { 15. Bermuda } & \text { 37. Grenada } \\ \text { 16. British Honduras } & \text { 38. St. Vincent } \\ \text { 17. Canada } & \text { 39. Argentina } \\ \text { 18. Canal Zone } & \text { Windward Islands } \\ \text { 19. Costa Rica } & \text { 40. St. Lucia } \\ \text { 20. Dominican Republic } & \text { 41. British Guiana } \\ \text { 21. El Salvador } & \text { 42. Chile } \\ \text { 22. Guatemala } & \text { 43. Colombia }\end{array}$

44. Ecuador
45. Uruguay
46. Venezuela
47. Aden (Colony)
48. Ceylon
49. China, Taiwan
50. Cyprus
51. India
52. Israel (Jewish)
53. Japan
54. Malaya, Federation of
55. Ryukyu Islands
56. Singapore
57. Hong Kong
58. Austria
59. Belgium
60. Bulgaria
61. Czechoslovakia
62. Denmark
63. Finland
64. France
65. Saar (West Germany)
66. West Germany

67. Gibraltar

68. Malta and Gozo

69. Hungary

70. Iceland

71. Ireland

72. Italy

73. Romania

74. Luxembourg

75. Netherlands

76. Norway

77. Poland

78. Portugal

79. Spain

80. Sweden

81. Switzerland

82. United Kingdom

83. Yugoslavia

84. American Samoa

85. Australia

86. Fiji Islands

87. Hawaii

88. New Zealand (European)

89. New Zealand (Maori)

Source: United Nations, Demographic Yearbook, 1957, p. 54.

Note: The dots on the diagonal show no change. Those below the diagonal show a decline in death rate. 
rate in Europe and North America during the 19th and 20th centuries was a phenomenon which emerged only gradually.

The sequence which occurred in Denmark may be regarded as illustrative though not necessarily typical. This is shown graphically in the following chart. It represents the change-over in a European country from a relatively stable population, with high death and high birth rates, to another level of relative population stability with lower death and birth rates.

By reason of the industrial and economic revolutions mentioned earlier, the population of all the industrial countries of the West was able to increase rapidly and live better at the same time.

Today, the demographic situation in the underdeveloped countries is basically different in two respects from that which prevailed in the industrialized countries during the 19th century:

(1) The population bases existing at the start of the industrialization process are in some cases very much larger.

(2) Because of the remarkable efficiency of modern public health techniques, the decline in the death rate today in many of the countries attempting to emerge from agrarian cultures is very much more rapid, than it was in Europe in the 19th Century. While it took fifty years in Denmark to bring the death rate down from 20 to 14, this change took place in Ceylon for example, in only one year. (1947-48) The birth rates have shown no evidences of decline. The result of this is a widening gap between the two and a rapid increase in population, currently over 3 per cent a year in many cases. Some of these populations already have a high density and all of them have a low per capita income.

There is a tendency in some discussions of this subject to assume that the demographic transition which occurred in Europe in the 19th century is some sort of a "law of nature" and that populations almost automatically go through such a transition. There is no evidence to support such a belief.

A recent report of the United Nations Economic Commission for Asia and the Far East comments on this question, with reference to Asian countries, in the following terms: ${ }^{1}$

"In the West, the demographic transition from a balance of high death and birth rates to a new balance of low death and birth rates was a slow and gradual process, in step with a similarly slow and gradual improvement in economic and social conditions. Per capita income, nutrition, housing and sanitation improved, the death rate gradually fell, and, after a time lag, the birth rate also fell. But in Asia and the Far East, the recent decline in mortality has been rapid, because it has resulted primarily from the introduction of advances in medicine and in epidemic control methods which had been developed elsewhere. In most of the countries, therefore, mortality has fallen

${ }^{1}$ Economic Bulletin for Asia and the Far East, June 1959. 
THE DEMOGRAPHIC TRANSITION IN DENMARK: $1735-1960$

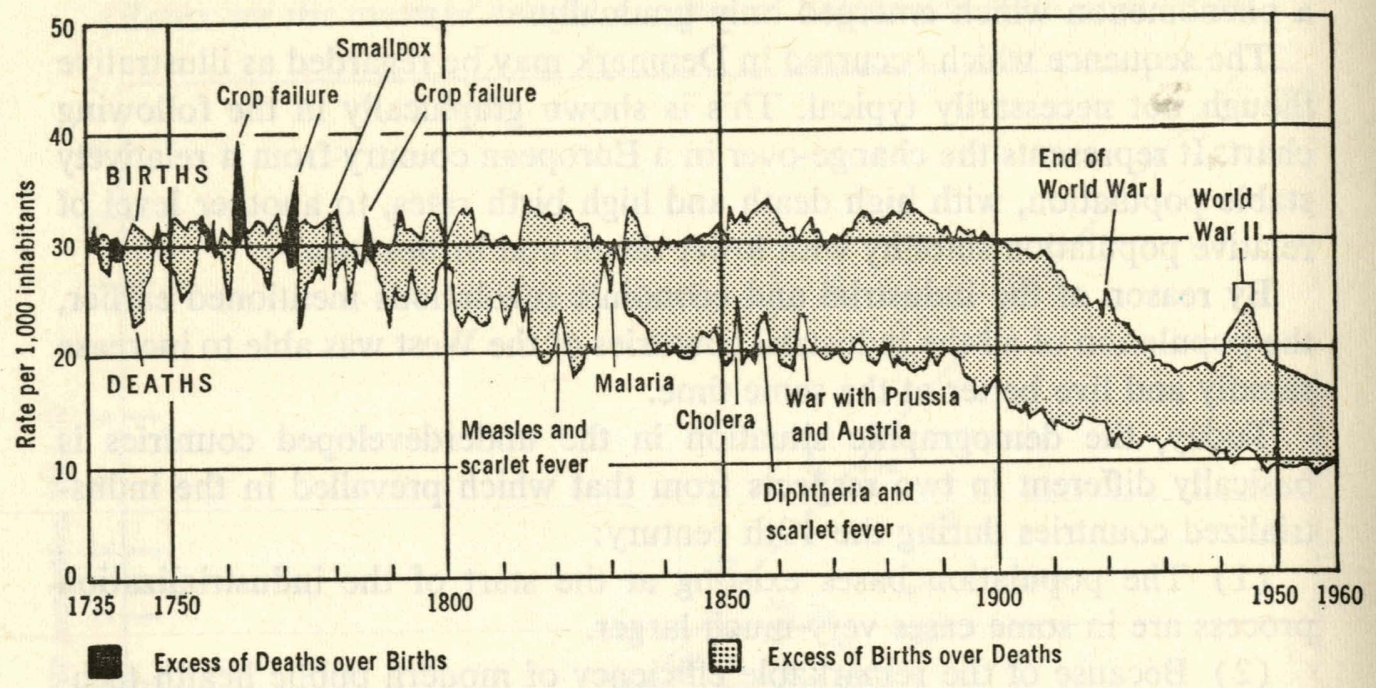

THE BEGINNING OF A DEMOGRAPHIC CHANGE IN CEYLON, 1900-1959

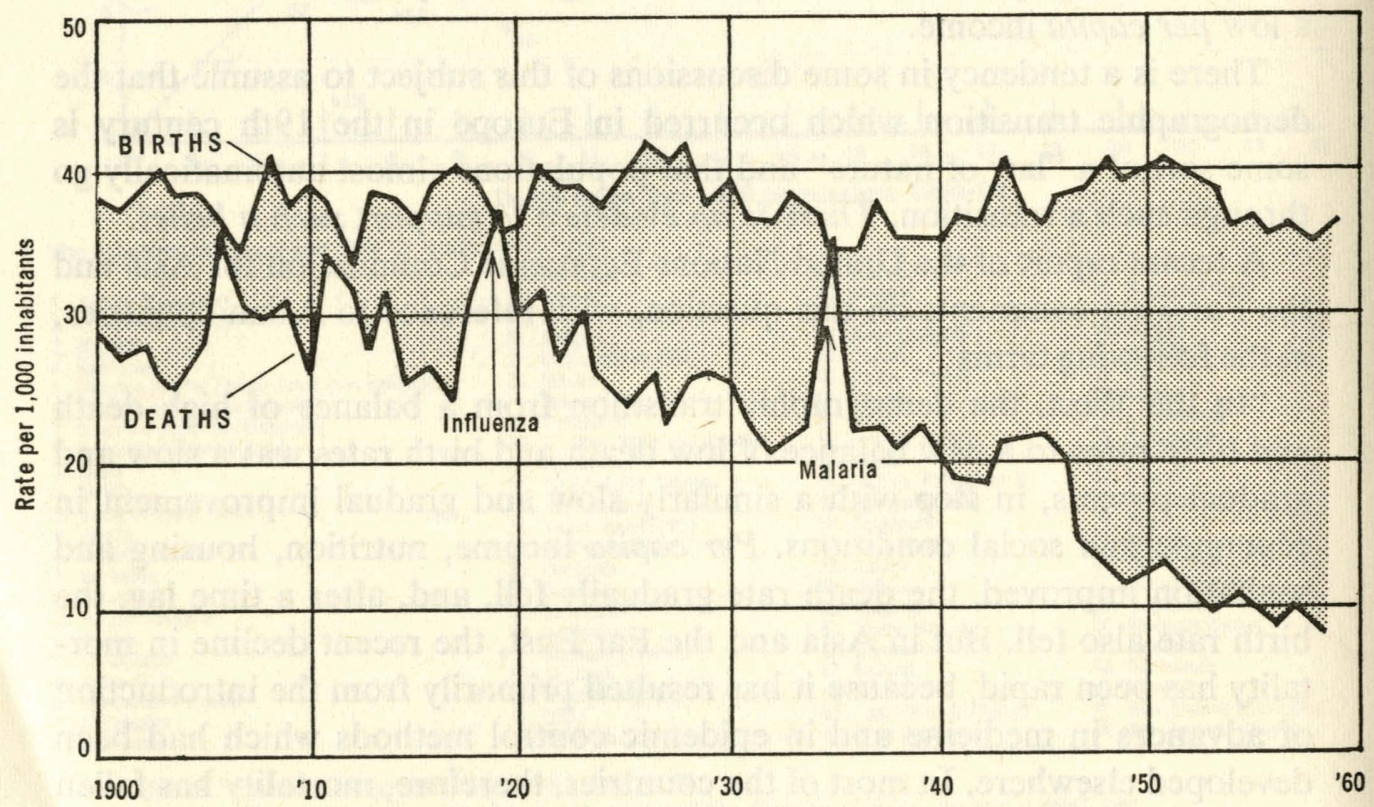

Source: Population Reference Bureau, Population Bulletin, Vol. X, No. 5, July 1954, pp. 60-61; United Nations, Demographic Yearbook, 1960. 
before any major improvement in social and economic conditions has occurred. If it be true that only after such a major improvement will the birth rate fall, a very long time may well elapse before the levels of living in the ECAFE countries are high enough to produce a new balance of low death and birth rates. In such circumstances the rapid rate of population growth which would occur in the interval would probably act as a brake on the economic development of most countries, and have a very important retarding effect in some cases. This is all the more true since the emigration outlet, which provided substantial relief to population pressure in Europe during its demographic transition, is not available to Asian countries to any significant extent."

"However, past correlations between rising per capita income and declining fertility are not enough to establish an inevitable relationship between the two." 


\section{Food Needs in Relation}

\section{to Population Growth}

\section{in Various Regions}

Although it is unfortunately true that gluts of food arise periodically in those areas in which there is least need for more food, it is equally true that a majority of the people now living on the earth do not have enough to eat, and unless the present rate of expansion in food production is greatly accelerated, their hunger will not be appreciably assuaged within the next decades. Thus, in the light of present population trends, the efforts now being made to solve the world's problem of hunger are not realistic.

In the world picture of food needs and population growth, these four features deserve to be highlighted:

(i) Demographic changes take place slowly. There is no prospect that there will be a sudden decline in the world birth rate. Barring catastrophes, there is a good prospect that the world death rate will decline still further. Hence, during the immediate future extending over the next few decades, there is every prospect that population growth will continue at a rapid rate.

(ii) A vast increase in the production of food to meet the inevitable population increases over the next decades is imperative if appalling disasters are to be averted and the possibility of an orderly and constructive transition to a satisfactory, stable balance between food and population is to be assured.

(iii) If such a transition is to be achieved, the magnitude of the operation must be recognized. It is all very well to say that "much more food can be produced." To create the technology and the education and the storage and transportation facilities and everything else required to bring this transition to pass is an operation on a scale far vaster than anything contemplated in the plans either of individual governments or of the co-operative undertakings now contemplated by United Nations agencies.

(iv) Indefinite multiplication of people on a finite planet is impossible. If the rate of population growth which is occurring in some areas of the world today were to be applied to the total human population of the planet, 
within only two or three centuries the entire land surface of the earth would be covered with human beings.

There is a definite limit to the number of human beings that the earth can accommodate. It would not be realistic, at the present stage of scientific development, to take into account space travel and other technological advances as factors offering a possible solution to the problem. If there is ever to be enough and to spare for all-if the promises of security, and freedom from hunger and fear are to be realized-stabilization of population will eventually be unavoidable. How long it can be postponed without the gravest consequences is one of the most important questions facing humanity today.

\section{Population predictions}

The question of the amount of food necessary to feed future populations hinges on the balance of births and deaths around the world. The critical area is represented by the 2,000 million people living in the high-birth-rate, technologically-underdeveloped countries. Given the many efforts to increase their food supplies, what is the prospect for population growth in these countries in the future, and how accurately may this growth be predicted?

During the 19th century, several attempts were made to predict population growth by applying an all-embracing mathematical formula, and similar ideas have recently been revived, but the results so far achieved serve to demonstrate that no generalized formula can anticipate what impact fortuitous events such as, for example, the depression of the 1930's and the subsequent economic recovery, will have on the birth rate. Barring catastrophe it can be assumed that the low death rates of the industrial countries will remain relatively stable; but catastrophes can happen and these could profoundly alter future population growth.

It may be stated, however, that the difficulties of population prediction are greatest when an attempt is made to predict the population growth of any particular country. Predictions concerning the regional and world situation are likely to be more reliable since local perturbations in vital rates may not affect the results to such a large extent.

Models of population growth may be based on various assumptions concerning changes in birth and death rates. These models at least afford some insight into the order of magnitude of changes which may be expected during the next forty years. If no major unexpected factors, whether favourable or unfavourable, upset the foreseeable trend of population growth, future developments should be as follows: World population is now about the 3,000 million mark. It increased by over 400 million in the 1950 decade. It is estimated to increase by about 600 million in the 1960 decade, or at the rate of about 60 million persons per year; at this rate, world population will double in about forty years-reaching 6,000 million before the year 2000 . 
And with falling death rates in many areas of traditionally high birth rates, the population in the year 2000 could conceivably exceed this figure by 1,000 million.

The rates of population growth which now exist offer scant prospect of improved economic conditions for the people of the underdeveloped countries; in fact, the reverse is the case. During the next decade, if present trends are maintained the world will tend to become divided even more markedly into two distinct groups, as follows:

(i) The demographically stable, industrialized nations enjoying relatively high levels of living, where effective fertility regulation exists or is developing. This includes the whole of Europe, the Soviet Union, North America, the temperate-zone countries of Latin America, Oceania and Japan.

(ii) The demographically unstable, largely subsistence-level countries that are now struggling toward economic development; almost two thirds of the world's people live in these countries. In none of them does there seem to have been any effective effort to reduce fertility, except on the part of numerically insignificant minorities of the population. This group of countries includes all non-Soviet Asia (except Japan and Israel), tropical Latin America, and most of Africa. The "rising expectations" that swept the world of the early 1950 's are in danger of being extinguished by the new multitudes born into very marginal conditions of living, and needing to be fed, clothed and housed.

WORLD POPULATION CHANGES, 1920 TO 2000

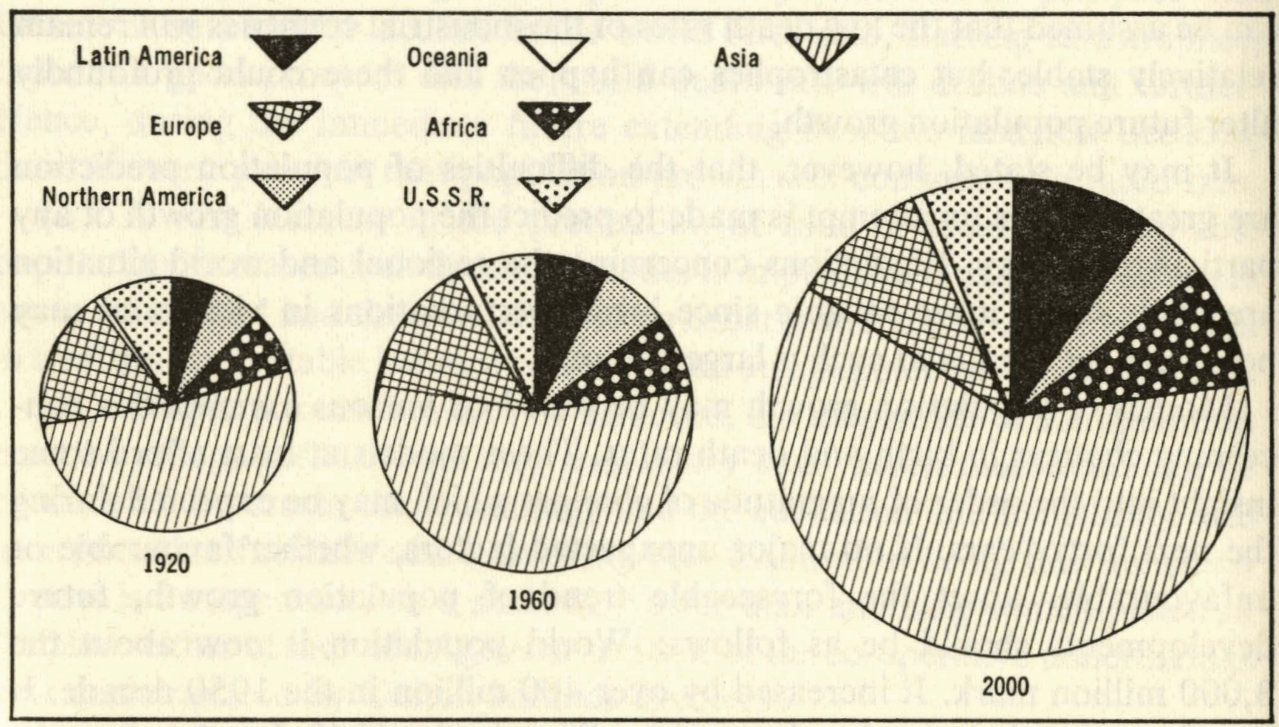

The areas of the circles represent the total population of the world. If present trends continue, 9.4 percent of the world's population will be found in Latin America in 2000 as compared with about 7 percent today. 
As a result of the very large differences in rate of increase, the proportions of the population living in various parts of the world are expected to change significantly. According to the United Nations medium assumption, Asia's share is likely to increase from 55.2 per cent in 1950 to 62 per cent in 2000 and Latin America's from 6.5 per cent to more than 9 per cent, while Africa's share would remain constant at about 8 per cent. The share of Europe including the USSR, would decline from 23.0 per cent in 1950 to 15 per cent, and that of northern America from nearly 7 to about 5 per cent. Oceania's proportion would probably remain at its present 0.5 per cent.

The population of Asia is growing very rapidly: according to United Nations' projections, Asia which now has more than 1,600 million people (excluding the Asian part of the USSR) may have 2,000 million by 1975 and 3,900 million by 2000 . This estimate is based on the assumption that mortality will continue to decline but that fertility will remain at its present high level until 1975 and then gradually decline.

The report of the United Nations Economic Commission for Asia and the Far East (ECAFE) mentioned earlier, indicates that if present trends in growth continue, the population of the region will nearly double in the next thirty years and will then nearly equal the entire world population today.

Within the next two decades, increasing population pressure could completely frustrate the rising hopes for a new way of life among the people of the ECAFE region. Governments are hard pressed to find the resources to

PERCENT POPULATION INCREASES BY MAJOR REGIONS,

1900 Tо 2000

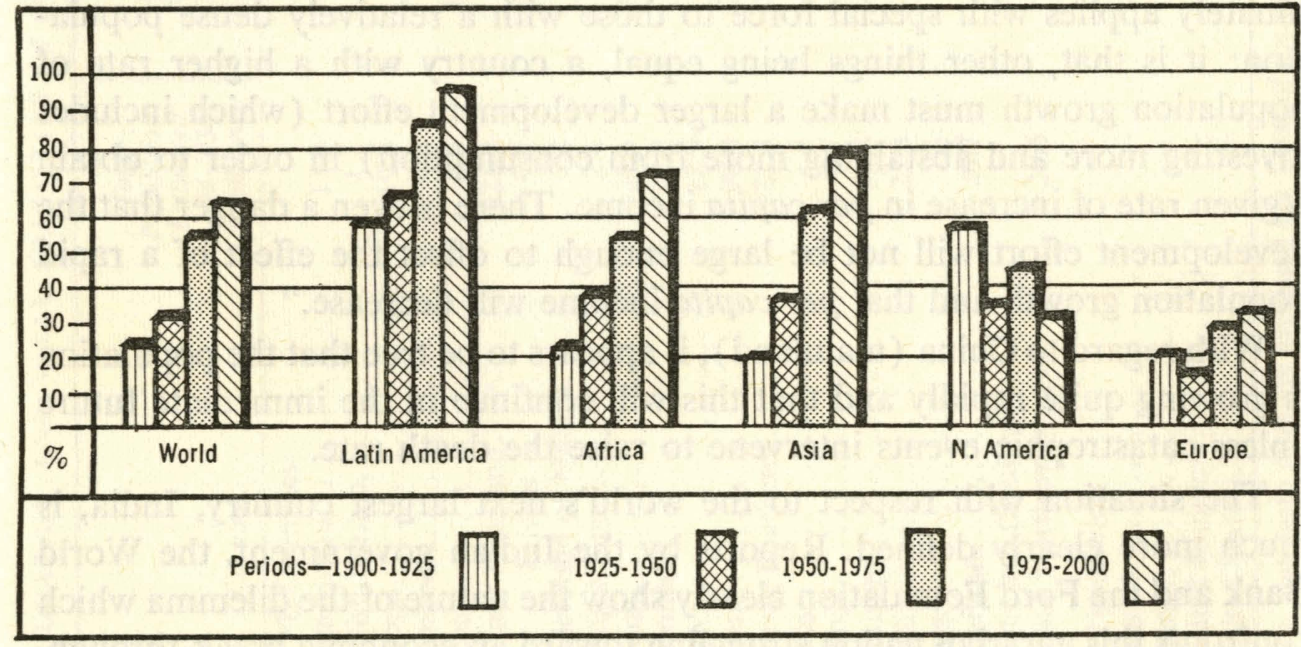

The United Nations projections to the year 2000 show a relatively small increase in population in western Europe and North America and the greatest increases in Latin America and Asia.

Source: Population Reference Bureau, Population Bulletin, Vol. XV, No. 2, March 1959, p. 28. 
stimulate economic development so that the legitimate demands for increased per capita consumption can be met.

Table 2 compares the population of the ECAFE region with that of other major regions of the world. The figures are derived from official statistics where these are deemed to be adequate, or are estimates based on models constructed by the United Nations. The figures cited for mainland China have been compiled from various releases of the Government.

China (mainland and Taiwan) and India, the world's largest nations, account for almost 70 per cent of all the people in the ECAFE region. After these, Indonesia, Japan and Pakistan, each with 80 to 90 million people, have larger populations than any other nations of the world except the United States and the Soviet Union.

High birth rates and rapidly falling death rates account for the increasing rate of population growth throughout most of the region. Japan is an urban, industrial nation, with birth and death rates similar to those of Western countries rather than the ECAFE countries. Since 1948-1949, the rate of growth in Japan has decreased under the impact of the falling birth rate. The higher levels of literacy and industrialization are certainly factors in this rapid decline in births.

The economic implications of Asia's rapid growth trend are serious since most of the countries of the region have low income, low literacy, limited cultivated land, limited capital resources, and few developed natural resources other than land.

The ECAFE Report above-mentioned states a generalization which, it considers, is "valid for all but a few sparsely populated countries, and unfortunately applies with special force to those with a relatively dense population: it is that, other things being equal, a country with a higher rate of population growth must make a larger development effort (which includes investing more and abstaining more from consumption) in order to obtain a given rate of increase in per capita income. There is even a danger that the development effort will not be large enough to offset the effect of a rapid population growth and that per capita income will decrease."

With regard to China (mainland), it appears to be true that the population is growing quite rapidly and that this will continue in the immediate future unless catastrophic events intervene to raise the death rate.

The situation with respect to the world's next largest country, India, is much more clearly defined. Reports by the Indian government, the World Bank and the Ford Foundation clearly show the nature of the dilemma which confronts this agrarian nation struggling toward an economic break-through. All these surveys concur that rapid population growth represents a handicap to the success of plans to improve the economic conditions of the Indian people.

The situation in Africa and Latin America differs in scale and in other 
TABLE 2

POPULATION AND VITAL STATISTICS OF ECAFE COUNTRIES AND SELECTED COUNTRIES IN OTHER REGIONS

\begin{tabular}{|c|c|c|c|c|c|c|c|c|}
\hline \multirow[b]{2}{*}{ Country } & \multirow{2}{*}{$\begin{array}{c}\text { Total } \\
\text { Population } \\
\text { (Estimated } \\
\text { mid-1956) } \\
\text { (in millions) }\end{array}$} & \multicolumn{2}{|c|}{$\begin{array}{c}\text { Persons per } \\
\text { square kilometer } \\
\text { (Estimated 1956) }\end{array}$} & \multirow{2}{*}{$\begin{array}{l}\text { Crude } \\
\text { Birth } \\
\text { Rates* }\end{array}$} & \multirow{2}{*}{$\begin{array}{l}\text { Crude } \\
\text { Death } \\
\text { Rates* } \\
-(\text { Estima }\end{array}$} & \multirow{2}{*}{$\begin{array}{c}\text { Rates } \\
\text { of } \\
\text { Natural } \\
\text { Increase* } \\
\text { d 1954-56) }\end{array}$} & \multirow{2}{*}{$\begin{array}{l}\text { Infant } \\
\text { Mortality } \\
\text { Rates* }\end{array}$} & \multirow{2}{*}{$\begin{array}{c}\text { Life } \\
\text { Expectancy } \\
\text { at Birth } \\
\text { (in years) } \\
\text { (Estimated } \\
\text { 1950-55) }\end{array}$} \\
\hline & & $\begin{array}{l}\text { Total } \\
\text { Area }\end{array}$ & $\begin{array}{c}\text { Arable } \\
\text { Land }\end{array}$ & & & & & \\
\hline \multicolumn{9}{|l|}{ ECAFE Countries: } \\
\hline Afghanistan............. & 13.0 & 20 & 144 & - & - & - & - & - \\
\hline British Borneo............ & 1.1 & - & - & 46 & 29 & 1.7 & 253 & 29 \\
\hline 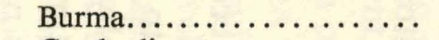 & 19.9 & 29 & 232 & 44 & 29 & 1.5 & 221 & 34 \\
\hline Cambodia.............. & 4.4 & 25 & 220 & 47 & 23 & 2.4 & 179 & 40 \\
\hline Ceylon................ & 8.9 & 136 & 586 & 42 & 14 & 2.8 & 128 & 54 \\
\hline China: Mainland......... & 621.2 & 64 & 568 & 37 & 17 & 2.0 & - & - \\
\hline Taiwan........... & 9.2 & 257 & 1,055 & 45 & 10 & 3.5 & 78 & 55 \\
\hline Federation of Malaya....... & 6.2 & 48 & 282 & 44 & 12 & 3.2 & 79 & 59 \\
\hline Hong Kong............ & 2.4 & - & - & 38 & 8 & 3.0 & - & - \\
\hline 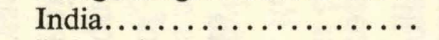 & 387.3 & 118 & 245 & 42 & 29 & 1.3 & 200 & 35 \\
\hline Indonesia.............. & 84.0 & 56 & 475 & 43 & 24 & 1.9 & 192 & 39 \\
\hline 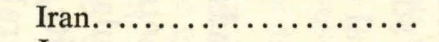 & 18.9 & 12 & 113 & - & 一 & - & - & - \\
\hline Japan................. & 90.0 & 243 & 1,783 & 19 & 8 & 1.1 & 42 & 66 \\
\hline Korea, Southern.......... & 21.8 & 225 & 1,093 & - & - & - & $\overline{0}$ & - \\
\hline 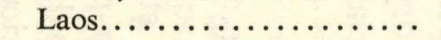 & 1.4 & 6 & 142 & 46 & 28 & 1.8 & 221 & 34 \\
\hline Nepal................ & 8.7 & 62 & 280 & - & - & - & - & - \\
\hline Pakistan............... & 83.6 & 88 & 343 & 50 & 30 & 2.0 & 200 & 35 \\
\hline Philippines........... & 22.3 & 74 & 347 & 49 & 21 & 2.8 & 166 & 44 \\
\hline Singapore............ & 1.3 & - & - & 48 & 9 & 3.9 & 49 & 63 \\
\hline Thailand..$\ldots \ldots \ldots \ldots \ldots$ & 20.7 & 40 & 265 & 47 & 23 & 2.4 & 179 & 40 \\
\hline $\begin{array}{l}\text { Viet-Nam (Southern } \\
\text { and Northern).......... }\end{array}$ & 26.6 & 81 & 591 & 43 & 22 & 2.1 & 一 & 一 \\
\hline \multicolumn{9}{|l|}{ Other countries: } \\
\hline Mexico.............. & - & - & - & 46 & 13 & 3.3 & 125 & 50 \\
\hline France...$\ldots \ldots \ldots \ldots \ldots$ & - & 一 & - & 19 & 12 & 0.6 & 39 & 68 \\
\hline United Kingdom........... & - & - & - & 16 & 12 & 0.4 & 26 & 71 \\
\hline United States............ & - & - & - & 25 & 9 & 1.6 & 28 & 71 \\
\hline
\end{tabular}

* Birth and death rates are expressed per 1,000 of the population per year. The annual rates of natural increase are given in percent of total

3, 4, 7, 8 and 10 in the Economic Bulletin for Asia and the Far East, June 1959 (op. cit.). They are either official statistics where these are adequate or they are estimates based on United Nations models. Data for mainpopulation. Infant mortality rates are per 1,000 live births per year. 
respects from that in Asia. The combined populations of Africa (over 240 million in 1960) and of Latin America (206 million in 1960) equal only a third of the total Asian population. Population density is very much lower, and the land-resource situation is more favourable. But as in Asia, there are vast gaps in statistical information. The same situation is found in all three areas with respect to the basic socio-economic and demographic factors. Birth rates persist at levels of $30,40,50$ or even more per thousand. Death rates are tending downwards-more rapidly in Latin America than in Africa. Among the results of this trend are a rapid growth in population and a high proportion of children with consequent very heavy demands for social capital.

In Latin America, the situation may be more favourable in the sense that the potential food and resource base is larger, but actual living conditions over large areas are marginal. In northeastern Brazil, actual famine conditions are reported, despite the fact that Brazil's agricultural resources are quite adequate to feed a much larger population than the current 66 millions. With a per capita income of less than $\$ 250.00$ and 42 per cent of the population under 15 years of age and with only half the adult population literate, the difficulties of utilizing available resources to meet the needs of the people of Brazil effectively are enormous.

The persistence of poverty and hunger in the face of the very real potential for food production and economic development in Brazil demonstrates a tragic truth: little advantage is gained from such a potential if the ability and capacity to exploit the natural resources and to build up social and economic capital do not proceed hand in hand with population growth. The large proportion of children in Brazil constitutes an unproductive segment of the population that requires not only food but also expensive investments in schools and health services. These requirements for social capital grow rapidly and divert capital resources from development of the means of production. The interplay of economic and demographic factors in this area as elsewhere, is extremely complex and can only be stated in general terms. Developmental economic theory is still in the exploratory stages and enjoys nothing like the elegance of classical economics.

\section{Relation of demographic trends to social and economic factors}

Despite many attempts by students of population to define and measure "over-population" and "under-population", no generally accepted indicators have been devised. Population density, while it is sometimes a useful indicator of population pressure on agricultural resources, does not take into account the relative abundance or availability through commerce of other natural resources, the extent of industrial development, or the degree of technological progress and other factors which are important determinants of welfare 
of the population. In recent years, attention has turned increasingly toward analysis of the relation between rates of population growth and factors influencing economic development, particularly for the under-developed countries where the need for economic progress has taken on such importance.

Certain trends are occurring throughout the world which complicate the social and economic situation. The first is a decline in the percentage of agricultural population, rapid in the developed regions, slower in the underdeveloped regions. The second is an increase in urban population, proportionately slower in the developed countries than in the underdeveloped countries. Third is the decline in importance of intercontinental migration since the early part of the 20 th century, as contrasted with its great importance in the 19th century. Fourth is the relatively rapid decline of death rates in the underdeveloped regions in recent years compared with the slower previous decline in the developed regions, without comparable declines in birth rates.

The effects of rapid population growth compared with slow or moderate growth are several:

(i) rapid population growth tends to increase the pressure of agricultural population on land which may already be densely settled, further complicating the effects of excessive fragmentation and land holdings so small as to be inefficient;

(ii) rapidly increasing population adds to the urgent need for capital investment to equip the growing labour force productively;

(iii) a high rate of growth adversely affects the ability of a population to realize needed investments in productive equipment. Additions to the population in labour-surplus countries do not increase proportionately the capacity to produce, but they do increase the necessity to consume and they put heavy demands on limited capital to meet social needs that are not immediately productive in economic terms but are nevertheless essential (schools and hospitals, for example). Consequently, under these conditions, population growth tends to reduce the amount of capital that can be invested in productive equipment;

(iv) the problem of saving and investing enough out of a limited annual income is made even more difficult by the need to provide for dependents. High birth rates result in a population with a relatively low percentage of people in the effectively productive age groups, so that, on the average, each person of working age will have to support a large number of dependents.

Thus, under conditions common to the underdeveloped regions, excessively rapid population growth tends to retard economic growth. Coale and Hoover $^{2}$ estimate that if India's birth rate should begin to decline by 1966

\footnotetext{
${ }^{2}$ Coale, Ansley J. and Edgar M. Hoover. Population Growth and Economic Development in LowIncome Countries, Princeton University Press, 1958.
} 
(instead of holding at the present level), by 1986 the proportion of national income invested would on that account be a third higher and income per capita would be increased by nearly a quarter! If the present rate of population increase should continue, given the conditions of economic development assumed in their analysis, not only would per capita income decline, but the gross national product would also begin to decline before the end of the period of these projections.

The "demographic transition" which took place under very unusual circumstances in the Western world during the preceding century is not likely to be repeated-is, in fact, not repeatable-in the same form in other parts of the world. The industrial and technical revolutions in the West made it possible to improve the living level in the face of quite rapid population growth. The populations of the Western industrial countries in general at least tripled during the transition.

It is a tragic paradox that as the industrial countries have been moving steadily toward stabilization of population growth, the far more populous and relatively underdeveloped agrarian countries have been experiencing a rapid acceleration in population growth. While the demographically stable industrial nations are moving toward higher economic levels, the demographically unstable two-thirds of the human race in the agrarian countries are barely able to make any improvement in their marginal levels of existence. 


\section{Cities and Food}

The agricultural revolution, the increasing power to control epidemic diseases, and improved transportation have all combined to usher in a new era in the growth of cities. The city, in turn, has had far-reaching influences on the quantities and qualities of both mouths and calories-and its influences have greater and greater force today, in the economically "developed" as well as the economically underdeveloped countries.

As has been pointed out above, world population is growing at an unprecedented rate today; and the rate of growth of urban populations is even greater. Today, over 20 per cent of the world's people, or more than 500 million live in urban areas of 20,000 or more inhabitants, compared with only about 2 per cent in 1800 . Over three-fifths of today's city dwellers (13 per cent of total world population) live in cities of 100,000 or more.

The United Nations Report on the World Social Situation, $1957^{3}$, referring to the sudden spurt of urban growth in underdeveloped countries in recent years, points out that by 1950 Asia had one-third of the world's total largecity (100,000 or more) population. Comparing the trends of urban and rural population growth in various parts of the world, the Report points out that whereas in the majority of the less-developed countries the rural population has also increased, though at a slower rate, the absolute size of the rural population in many of the more developed countries has remained stationary or even declined.

In 1950, the world's major regions of industrial urban settlement were Australasia, northwestern Europe, northern America, northeast Asia, and southern South America. These areas included about 25 per cent of total world population but 52 per cent of the total living in cities of 100,000 or more. Australasia was the most heavily urbanized, with 47 per cent in cities of that size.

During the past twenty years, the USSR has been undergoing extensive urbanization. In 1959, 48 per cent of the USSR population was living in cities, compared with only 32 per cent in 1939 . In twenty years, the urban population grew by almost 40 million, an increase of two-thirds. In 1949 , 23 per cent of the total population and almost 50 per cent of the urban population lived in cities of 100,000 or more. 
It has been estimated that 20 million mainland Chinese migrated from rural to urban areas between 1949 and 1956. Mainland China's inland cities have experienced a remarkable rate of growth. Estimates indicate that in the western provinces alone, Lanchow grew from 200,000 in 1950 to 680,000 in 1956; Paotow from 90,000 in 1949 to 430,000 in 1957 and Kalgan from 270,000 in 1949 to $1,050,000$ in 1957 . Furthermore, there is a heavy concentration of mainland China's urban population in the larger cities.

In some regions of the world, a single large city-usually the capital citycontains a high proportion both of a nation's total population and of its urban population. In many countries, well over 50 per cent of all the urban population is concentrated in the capital city. This is especially true of several Latin American countries. More than one-fourth of all Latin Americans live in cities of 20,000 or more and about one-fifth live in cities of 100,000 or more.

The consensus of competent opinion appears to be that in the world as a whole, the trend toward the city is by no means at an end. Even in the highly urbanized industrial nations of the Western world, it appears that the proportion of the population residing in major metropolitan agglomerations will continue to grow. The rural population, which is by no means entirely devoted to agricultural pursuits at the present time, constitutes less than 20 per cent of the total; the farming population is less than 10 per cent.

In the agrarian countries, an overwhelming majority still lives on the land. There, employment is to a large extent inadequate and unproductive, so the present large drift to the city can be expected to continue. The effect of this migration will largely depend on the speed with which industry will be able to create jobs.

\section{How urbanization affects food supplies}

The persistent and accelerating movement of population towards the cities increases the already complicated problem of hunger in the economically less-developed regions of the world. This fact is significant for the following reasons:

In the first place, an increase in the supply of marketable food is needed. A greater output of food does not necessarily result in a greater surplus for the urban population, and in countries where farming is still at subsistence level the farm population, itself increasing, may consume much of its increased output rather than selling it. Therefore, the production of food must rise considerably faster than the growth of the farm population if there is to be enough food for urban markets.

Secondly, more food must be taken to the cities, and for this, better transportation facilities are needed. In many cases these are practically nonexistent or are totally inadequate to meet the new demands made on them.

Thirdly, facilities for storing and preserving food must be set up, particularly where large year-to-year fluctuations in crops make it difficult to secure 
a steady supply of food. At present there is a high proportion of waste in the underdeveloped regions and stored food is often spoiled by rats, mice and insects.

Lastly, food supply is not the only problem connected with urbanization, housing, health and civic services are needed, and capital is often diverted from the production and distribution of food to social development programmes.

The United Nations Report on the World Social Situation ${ }^{4}$ sums up the problem as follows:

'Ideally, productivity in agriculture would rise at a rate meeting the cities' growing demands for food as well as the demands of export markets while permitting the release of agricultural workers at a rate meeting the rising demand for labour in industry and services. In practice the transition does not proceed so smoothly, and in many countries today something quite different is happening: productivity is hardly increasing at all, while masses of rural workers come to the cities looking for jobs that either do not exist or from which they are barred by illiteracy and lack of skills." 


\section{Present Food Supplies}

\section{and Estimated Future Requirements}

\section{Present food deficits}

There are vast differences in diets throughout the world. These reflect such factors as types of crops and livestock produced, food preferences, level of living, and amount of trade.

The common pattern in most countries is a basic reliance on staple cereals and starchy foods. These are supplemented, when consumers can afford them, with the more expensive, nutritionally protective foods. As incomes rise above subsistence level, the more expensive foods are first added to diets and then begin to replace the staple foods.

Some idea of the imbalance in the relation between the population and the food production of various regions can be gathered from Table 3, which shows the relative shares of the world's agricultural production (nearly 90 per cent of which consists of food and food crops) and of the world's population in the various regions for the year 1958.

Most information on national diets consists of estimates of average food supplies available per person. In considering the information, two things must be kept in mind. First, the data that they are based on are often scanty or inadequate, so that the results are, at best, an approximation. Second, extensive studies have shown that even in the best fed countries of the world, there are large groups of people with low incomes whose diet is deficient in protective foods. Therefore, when a country's average per capita food supply is barely adequate, a large proportion of the population is subsisting on a sub-marginal diet. Despite these limitations, existing figures do provide a useful measure of the pattern of food consumption throughout the world.

By any standard, diets are poorest in the Far East, the region which contains over half the world's population. Throughout most of this region, the people have a daily average per capita calorie intake considerably below the standard estimated by FAO as adequate, taking into account the climate and physical size of the inhabitants. It is estimated that between 300-500 million of the population in this region is under-nourished and an additional 500 million do not get enough food of the right kind. The percentage of calories obtained from grains, starchy roots and sugar is an inverse indicator of 
quality of diet, and this figure is extremely high, in the Far East (about 80 per cent). Consumption of meats, vegetables, fruits, pulses, and other quality foods is correspondingly low. In terms of minimal adequate diet, therefore, the situation in this area is far from satisfactory.

TABLE 3

REGIONAL SHARES OF THE WORLD'S AGRICULTURAL PRODUCTION AND POPULATION FOR THE YEAR 1958

\begin{tabular}{|c|c|c|c|}
\hline REGION & $\begin{array}{l}\text { Agricultural } \\
\text { production } \\
\text { (per cent) }\end{array}$ & $\begin{array}{c}\text { Population } \\
\text { (per cent) }\end{array}$ & $\begin{array}{c}\text { Index of } \\
\text { Per Capita } \\
\text { production } \\
(\text { World average }=100)\end{array}$ \\
\hline Western Europe......... & 15 & 11 & 133 \\
\hline $\begin{array}{l}\text { Eastern Europe....... } \\
\text { (incl. USSR) }\end{array}$ & 17 & 10 & 162 \\
\hline Northern America....... & 21 & 7 & 316 \\
\hline Latin America......... & 8 & 7 & 121 \\
\hline Far East. $\ldots \ldots \ldots \ldots \ldots$ & 28 & 53 & 53 \\
\hline Near East............. & 4 & 4 & 90 \\
\hline Africa............. & 4 & 7 & 60 \\
\hline Oceania............. & 3 & 1 & 583 \\
\hline WORLD TOTAL......... & 100 & 100 & 100 \\
\hline
\end{tabular}

Source: Estimates supplied by FAO.

While the energy content of the diet in Africa is higher than in the Far East, the quality of the diet is poorer due to the heavy dependence on starchy foods. Diets in the Near East and Latin America are generally better than those in the Far East and in Africa. Many of these countries have an average per capita intake of over 3000 calories; but in other countries the diet is below this level. The greatest need of these regions is for proteins of high nutritive value. In the rest of the world, particularly the industrialized countries, the situation is much better. Intake of calories averaged about 3000 per capita and the proportion derived from grain, starchy roots and sugar ranges from 40 per cent in North America to about 63 per cent in Europe.

A comparison of estimated levels of per capita consumption of food for immediate pre-war, early post-war, and recent periods is shown in Table 4.

Two points are readily apparent from that table. The diets in the developed and under-developed countries are widely different in all three respects. While the developed countries have surpassed pre-war levels of calories and proteins, the under-developed countries are still below pre-war levels of proteins, and only just above pre-war levels of calories. This is in 
spite of the great efforts that have been made to increase the world's food supplies.

How far are existing levels below desirable levels? Exact measurement is difficult because while there is general agreement on what characterizes good and poor diets, there is no widespread agreement on nutritional requirements or standards except for calories.

TABLE 4

LEVELS OF DAILY PER CAPITA CONSUMPTION OF FOOD BY REGIONS AND GROUPS OF COUNTRIES

\begin{tabular}{|c|c|c|c|c|c|c|c|c|c|}
\hline \multirow[b]{2}{*}{ Regions } & \multicolumn{3}{|c|}{ Calories } & \multicolumn{3}{|c|}{ Total protein (grams) } & \multicolumn{3}{|c|}{ Animal protein (grams) } \\
\hline & $\begin{array}{l}\text { Pre- } \\
\text { war }\end{array}$ & $\begin{array}{c}\text { Immediate } \\
\text { Post- } \\
\text { war }\end{array}$ & Recent & $\begin{array}{l}\text { Pre- } \\
\text { war }\end{array}$ & $\begin{array}{c}\text { nmedic } \\
\text { Post- } \\
\text { war }\end{array}$ & Recent & $\begin{array}{l}\text { Pre- } \\
\text { war }\end{array}$ & $\begin{array}{c}\text { nmedia } \\
\text { Post- } \\
\text { war }\end{array}$ & $\begin{array}{l}\text { te } \\
\text { Recent }\end{array}$ \\
\hline Far East........... & 2120 & 1910 & 2070 & 63 & 54 & 56 & 8 & 6 & 8 \\
\hline Near East........... & 2320 & 2190 & 2470 & 76 & 70 & 76 & 15 & 14 & 14 \\
\hline Africa............ & 2180 & 2100 & 2360 & 61 & 61 & 61 & 15 & 15 & 11 \\
\hline Latin America....... & 2140 & 2380 & 2470 & 66 & 67 & 67 & 30 & 29 & 25 \\
\hline Europe........... & 2850 & 2870 & 3040 & 85 & 91 & 88 & 27 & 31 & 36 \\
\hline Northern America... & 3140 & 3120 & 3120 & 89 & 90 & 93 & 50 & 60 & 66 \\
\hline Oceania............ & 3270 & 3180 & 3250 & 97 & 95 & 94 & 65 & 65 & 62 \\
\hline Group $I^{*} \ldots \ldots \ldots$. & 2130 & 1960 & 2150 & 63 & 56 & 58 & 10 & 8 & 9 \\
\hline Group $\mathrm{II}^{*} \ldots \ldots \ldots \ldots$ & 2910 & 2850 & 3060 & 86 & 91 & 90 & 33 & 40 & 44 \\
\hline World............ & 2410 & 2260 & 2420 & 72 & 66 & 68 & 18 & 18 & 20 \\
\hline
\end{tabular}

Source: Sukhatme, P. W. (1961), "The World's Hunger and Future Needs in Food Supplies," The Journal of the Royal Statistical Society, Series A (General); Vol. 124, page 477.

* The Group I countries include the Far East, Near East, Africa and Latin America (except River Plate countries). The Group II countries include Europe, northern America, River Plate countries and Oceania. These groups correspond fairly closely to the under-developed and developed countries of the world.

However, in recent studies conducted in FAO certain targets have been set for daily per capita consumption of calories and animal proteins and the comparison of these targets with estimated actual levels of consumption affords at least an approximate indication of the extent of present deficiencies. For calories, these targets are based on the widely accepted FAO calorie requirement scale. Those for animal proteins are based on the consideration to bring the quality of the diets in the under-developed countries somewhat closer to the levels enjoyed by the developed countries in so far as this is feasible and advisable under the conditions of the under-developed countries. Such a comparison is shown in Table 5 for the four "under-nourished" 
regions: Far East, Near East, Africa, and Latin America except the River Plate countries.

While the present averages of consumption of calories in the Near East, Africa and Latin America are at or near the target figures, there is a deficiency of some 10 per cent in the Far Eastern region. Deficiencies of animal protein consumption are however more serious, and this is so not only in the Far East, but in the Near East and Africa as well.

\section{TABLE 5}

PRESENT LEVELS AND MINIMUM TARGETS FOR DAILY PER CAPITA CONSUMPTION OF TYPES OF FOODS IN UNDER-NOURISHED AREAS OF THE WORLD

\begin{tabular}{|c|c|c|c|c|c|c|c|c|c|c|}
\hline & \multicolumn{2}{|c|}{ FAR EAST } & \multicolumn{2}{|c|}{ NEAR EAST } & \multicolumn{2}{|c|}{ AFRICA } & \multicolumn{2}{|c|}{ LATIN AMERICA* } & \multicolumn{2}{|c|}{$\begin{array}{c}\text { TOTAL } \\
\text { UNDERNOURISHED } \\
\text { AREAS } \\
\end{array}$} \\
\hline & Present & Target & Present & Target & Present & Target & Present & Target & Present & Target \\
\hline $\begin{array}{l}\text { Calories. . } \\
\text { Animal }\end{array}$ & 2070 & 2300 & 2470 & 2470 & 2360 & 2460 & 2370 & 2410 & 2150 & 2340 \\
\hline $\begin{array}{l}\text { Protein. } \\
\text { (grammes) }\end{array}$ & 8 & 15 & 14 & 20 & 11 & 20 & 19 & 20 & 9 & 16 \\
\hline Index.... & 100 & 141 & 100 & 117 & 100 & 128 & 100 & 105 & 100 & 133 \\
\hline
\end{tabular}

Source: Sukhatme P. V. (op. cit.), pp. 498 and 504.

- Excluding River Plate countries.

The "index" shown in this table represents the proportionate increase in per capita consumption required to achieve a minimum level of adequate diet at the least cost, within realistic possibilities of change. The data indicate that the level of diet in the under-developed countries of the world would have to be raised by a third, on the average, to achieve these targets.

\section{Trends in demand for foodstuffs}

A number of factors have an important bearing on the trends in demand for foodstuffs. Probably the most important factor influencing the total world demand is that of population growth. The average growth of world population from 1950-59 has been estimated at 1.7 per cent per year, but this rate varies by regions from less than 1 per cent in Europe to nearly 3 per cent in Middle America (Central America, Mexico, and the Caribbean region).

The age and sex composition of population also influence food requirements since the needs of children, women, and men vary. The large proportion of children in rapidly growing populations, discussed before, may reduce 
average calorie requirements to some extent. But this is probably outweighed by the fact that children and young adults both need large amounts of proteins.

A third factor, as we have seen, is urbanization, and a fourth is the effect of rising incomes on food consumption.

Post-war experience has demonstrated the accuracy of the 1943 Hot Springs Conference declaration that "The first cause of hunger and malnutrition is poverty." The demand for food at existing levels of income in the under-developed countries often does not produce diet which is sufficiently nutritious.

TABLE 6

ESTIMATED PERCENTAGE OF CALORIES DERIVED FROM

CEREALS, STARCHY ROOTS, AND SUGARS FOR

AREAS AND SELECTED COUNTRIES

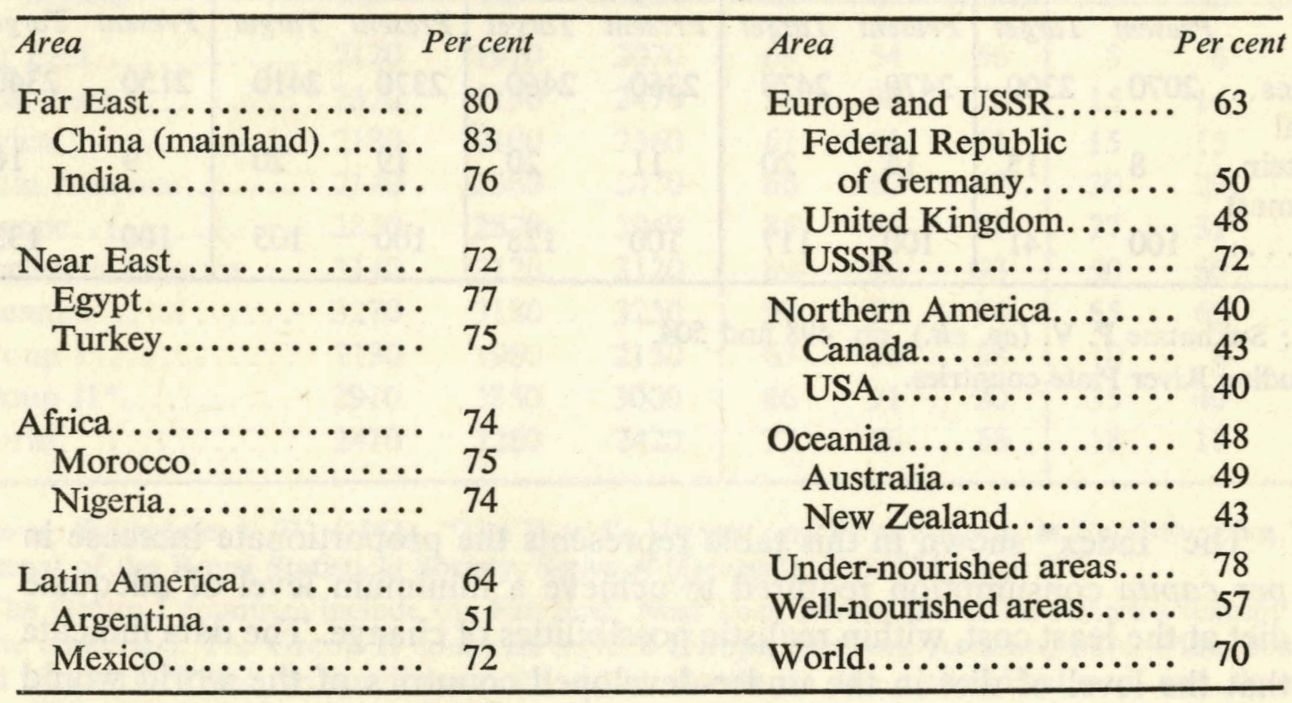

Source: Sukhatme (op. cit.), page 493.

Studies by $\mathrm{FAO}^{4}$ indicate a remarkable uniformity in the relation between income and expenditure on food over a wide range of countries at different levels of income and economic development, despite wide variation in cultures and food habits. In economies where most of the population is at the margin of subsistence, the main effect of an increase in income will be an increased demand for food. In such countries, an increase of one per cent in income leads to an increase of between 0.7 and 0.8 per cent in demand for food. This ratio may be referred to as the "income elasticity of food."

${ }^{4}$ FAO, State of Food and Agriculture, 1957, pp. 70-110; 1960, p. 113. 
But as average income increases, the demand for food does not increase in the same proportion. Therefore, if the programmes for economic development in the under-developed countries should succeed in raising per capita income for any length of time, the induced demand for food would eventually abate at a higher level of consumption. None the less, this immediate increased demand is an important consideration in the development of countries with low incomes.

In the more developed countries, the "income elasticity of food" described in the preceding paragraph, is about 0.4 ; for grains and starchy foodstuffs, it is lower still, and even assumes a negative value. Thus, an increase in per capita incomes in these countries leads to a relative decline in demand for basic foods, and contributes to the food surpluses that have appeared in some relatively advanced countries.

The difficulty of obtaining satisfactory nutrition under low-income conditions is indicated by the figures in Table 7 which shows the number of hours a worker receiving the average manufacturing wage rate in specified countries must work to earn the cost of one day's food for one person at three dietary levels. The first dietary level is representative of economically underdeveloped countries; the second, of countries at an early stage of industrialization, the third, of economically advanced countries. Each diet is composed and priced in terms of food customarily eaten in the specified country.

Clearly, the more nutritious and expensive diets are beyond the means of the average factory worker with a family in the economically under-developed

\section{TABLE 7}

NUMBER OF HOURS OF WORK REQUIRED FOR AN AVERAGE FACTORY WORKER TO EARN THE COST (AT 1953 RETAIL PRICES) OF THREE REPRESENTATIVE

DIETS FOR ONE PERSON FOR ONE DAY, IN SELECTED COUNTRIES

\begin{tabular}{|c|c|c|c|}
\hline & Diet 1 & Diet 2 & Diet 3 \\
\hline Calories........................... & 2100 & 2500 & 3000] \\
\hline Grammes animal protein............... & $10-12$ & $15-20$ & $40-45$ \\
\hline \multicolumn{4}{|l|}{ Hours of work required: } \\
\hline India........................... & 2.1 & 2.9 & 4.5 \\
\hline 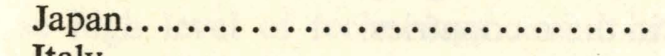 & 1.8 & 2.3 & 3.8 \\
\hline Italy $\ldots \ldots \ldots \ldots \ldots \ldots \ldots \ldots \ldots \ldots \ldots$ & 1.1 & 1.5 & 3.2 \\
\hline Mexico $\ldots \ldots \ldots \ldots \ldots \ldots \ldots \ldots \ldots \ldots$ & 0.6 & 0.8 & 1.4 \\
\hline Sweden...................... & 0.4 & 0.6 & 0.9 \\
\hline Denmark...................... & 0.3 & 0.4 & 0.7 \\
\hline Canada.......................... & 0.2 & 0.3 & 0.5 \\
\hline United States................... & 0.2 & 0.2 & 0.4 \\
\hline
\end{tabular}

Source: FAO, State of Food and Agriculture, 1957, p. 108. 
countries. Moreover, since the incomes of factory wage-earners are usually higher than the incomes of farmers and farm workers, and the latter make up the bulk of the labour force in under-developed countries, the calculations of hours of work shown in the table may well be optimistic.

The importance of income in determining both the level and pattern of food consumption indicates the essential connexion between economic development and progress in nutrition. As the 1957 FAO report on the State of Food and Agriculture points out, no substantial improvement in nutrition is likely until productivity is raised and the general run of people in a country earn higher incomes, although there may be some improvement for the population as a whole and major improvements for special groups such as expectant and nursing mothers, and children of school and preschool age. Such improvements may be brought about, in the absence of income changes, by such means as nutritional education and special welfare schemes.

\section{Population growth and food requirements}

In considering how population growth affects the need for food, it should be made clear that the statement on page 25 above, that "the level of diet in the under-developed countries of the world would have to be raised by a third" if minimum dietary targets are to be achieved, applies only to existing population levels and does not take into account the additional food which will be needed for growing populations. When FAo's First World Food Survey was published in 1946, the growth of world population was estimated at about 1 per cent per year. The current estimates quoted above show an average rate of 1.7 per cent in the world as a whole during the 1950's, and the future projections indicate even more rapid growth. In the developed countries, which are already enjoying adequate average levels of nutrition, population is expected to increase 28 per cent over the 1958 level by 1980 . On the other hand, the population of the under-developed countries as a group is expected to increase by 56 per cent.

The estimates shown in Table 8 indicate that food supplies in the underdeveloped countries must more than double between 1958 and 1980 if the increasing population is to be fed at a minimum adequate nutritional standard. This means an annual average rate of increase of nearly $31 / 2$ per cent in food supplies. This is a higher rate than the average annual increase in food production over the past seven years in these countries.

Although annual increases of food production for the world as a whole have been greater than this over the past few years, much of the increase has taken place in the economically developed countries. Moreover, although in under-developed countries, agricultural production has increased only somewhat faster than population growth, the situation is entirely different in the economically developed countries. Food supplies in countries which were 
TABLE 8

PERCENTAGE INCREASES OF FOOD SUPPLY NEEDED DURING 1958-1980 TO MEET ANTICIPATED REQUIREMENTS IN VARIOUS

REGIONS OF THE WORLD

\begin{tabular}{|c|c|c|c|c|c|}
\hline & $\begin{array}{c}\text { Projected } \\
\text { population } \\
\text { growth } \\
1958-1980^{\mathrm{a}}\end{array}$ & $\begin{array}{l}\text { Per capita } \\
\text { increase of } \\
\text { food supply } \\
\text { presently } \\
\text { required to } \\
\text { meet target }\end{array}$ & $\begin{array}{l}\text { Total increase } \\
\text { of food supply, } \\
1958-1980 \\
\text { required to } \\
\text { meet target } \\
\text { and population } \\
\text { growth }\end{array}$ & $\begin{array}{c}\text { Rate of } \\
\text { annual } \\
\text { increase } \\
\text { needed } \\
1958-1980\end{array}$ & $\begin{array}{l}\text { Recent annual } \\
\text { rate of increase } \\
\text { in food supply }\end{array}$ \\
\hline \multicolumn{6}{|l|}{ REGIONS } \\
\hline \multicolumn{6}{|l|}{ Under-developed } \\
\hline Countries........ & 56 & 33 & 107 & 3.4 & 2.7 \\
\hline Latin America..... & $85^{c}$ & $5^{e}$ & $94^{\circ}$ & $3.1^{\mathrm{c}}$ & $2.5^{\mathrm{d}}$ \\
\hline Far East.......... & 55 & 41 & 86 & 2.9 & $3.0^{\circ}$ \\
\hline Near East......... & 62 & 17 & 90 & 3.0 & 3.1 \\
\hline Africa........... & 36 & 28 & 55 & 2.0 & 1.3 \\
\hline Developed Countries & 28 & - & 28 & 1.2 & 3.6 \\
\hline World........... & 48 & 14 & 69 & 2.4 & 2.9 \\
\hline
\end{tabular}

s Based on United Nations "Medium" projections as shown in "The Future Growth of World Population" (United Nations Publications, Sales No. 58 XIII 2).

b Computed from averages of food production in 1952/53 and 1959/60, FAO, State of Food and Agriculture, 1960, and FAO Yearbook, 1959.

- Excluding River Plate countries.

d Including River Plate countries.

excluding mainland China.

already adequately fed have increased, and, particularly in North America, surplus food stocks have developed despite sustained efforts to control production.

Thus, both in quality and quantity, the nutritional gap between the economically less advanced regions and the economically advanced countries has tended to widen.

These trends have been the result of the paradoxical supply and demand situation in developed and under-developed countries. In the economically advanced countries, agricultural output can be expanded easily because of the high level of technology and relatively abundant capital available to farmers. With food consumption already at a high level, increases in per capita income go mainly into non-agricultural goods. This, coupled with a moderate population growth, results in slow growth in markets for agricultural commodities, so surplus stocks have tended to accumulate.

In the less-developed countries, agricultural output is increased only with difficulty. With a rapidly growing population, demand is rising rapidly and, 
while a good deal of any increased income is spent on food, the low level of income precludes purchase at commercial prices of agricultural commodities produced by the advanced countries. Free or "cut-rate" distribution of food from the food-surplus areas could disrupt the agricultural economies of the under-developed areas, setting off a chain of reactions which would not be useful to discuss here.

Agricultural policies of the developed and under-developed countries

TABLE 9

GRAIN AREA, PRODUCTION AND YIELDS 1948-52 AND 1956-58, FOR REGIONS OF THE WORLD

(Area-million hectares; production-million tons; yield-tons per hectare.)

\begin{tabular}{|c|c|c|c|c|}
\hline & & $1948-52$ & $1956-58$ & $\begin{array}{c}\text { Percentage } \\
\text { increase }\end{array}$ \\
\hline World & $\begin{array}{l}\text { Area.............. } \\
\text { Production......... } \\
\text { Yield............. }\end{array}$ & $\begin{array}{r}609 \\
699 \\
1.15\end{array}$ & $\begin{array}{l}665 \\
911 \\
1.37\end{array}$ & $\begin{array}{r}9 \\
31 \\
9\end{array}$ \\
\hline Europe (exc. USSR) & $\begin{array}{l}\text { Area.............. } \\
\text { Productịon......... } \\
\text { Yield............. }\end{array}$ & $\begin{array}{r}72 \\
108 \\
1.50\end{array}$ & $\begin{array}{r}74 \\
132 \\
1.79\end{array}$ & $\begin{array}{r}3 \\
22 \\
19\end{array}$ \\
\hline Northern America & $\begin{array}{l}\text { Area.............. } \\
\text { Production......... } \\
\text { Yield............ }\end{array}$ & $\begin{array}{r}104 \\
169 \\
1.63\end{array}$ & $\begin{array}{r}94 \\
189 \\
2.01\end{array}$ & $\begin{array}{l}-9 \\
12 \\
23\end{array}$ \\
\hline Latin America & $\begin{array}{l}\text { Area............. } \\
\text { Production........ } \\
\text { Yield............. }\end{array}$ & $\begin{array}{r}28 \\
31 \\
1.11\end{array}$ & $\begin{array}{r}35 \\
41 \\
1.17\end{array}$ & $\begin{array}{r}25 \\
32 \\
5\end{array}$ \\
\hline Near East & $\begin{array}{l}\text { Area.............. } \\
\text { Production......... } \\
\text { Yield............. }\end{array}$ & $\begin{array}{r}22 \\
24 \\
1.09\end{array}$ & $\begin{array}{r}28 \\
31 \\
1.11\end{array}$ & $\begin{array}{r}27 \\
29 \\
2\end{array}$ \\
\hline Far East & $\begin{array}{l}\text { Area.............. } \\
\text { Production........ } \\
\text { Yield.............. }\end{array}$ & $\begin{array}{r}231 \\
252 \\
1.09\end{array}$ & $\begin{array}{r}257 \\
352 \\
1.37\end{array}$ & $\begin{array}{l}11 \\
40 \\
26\end{array}$ \\
\hline Africa & $\begin{array}{l}\text { Area.............. } \\
\text { Production........ } \\
\text { Yield.............. }\end{array}$ & $\begin{array}{r}41 \\
27 \\
1.52\end{array}$ & $\begin{array}{r}44 \\
30 \\
1.47\end{array}$ & $\begin{array}{r}7 \\
10 \\
-3\end{array}$ \\
\hline Oceania & $\begin{array}{l}\text { Area.............. } \\
\text { Production......... } \\
\text { Yield.............. }\end{array}$ & $\begin{array}{r}6.3 \\
6.8 \\
1.08\end{array}$ & $\begin{array}{r}6.2 \\
6.6 \\
1.07\end{array}$ & $\begin{array}{l}-2 \\
-3 \\
-1\end{array}$ \\
\hline USSR* & $\begin{array}{l}\text { Area.............. } \\
\text { Production........ } \\
\text { Yield............ }\end{array}$ & $\begin{array}{r}105 \\
81 \\
0.77\end{array}$ & $\begin{array}{r}126 \\
128 \\
1.02\end{array}$ & $\begin{array}{l}20 \\
58 \\
32\end{array}$ \\
\hline
\end{tabular}

* Includes pulses.

Source: FAO Production Yearbook, Volume 13. 
reflect the situation just outlined. In the more advanced countries, these policies have been aimed largely towards adjusting agricultural production to the level of domestic demand and commercial exports and towards bringing the incomes of farmers more into line with those of other occupations. These policies, however, have not been completely successful in achieving either aim. The result has been a trend towards lower relative farm incomes and unused production.

In the less-developed countries, agricultural policies have, in contrast, been aimed largely at increasing agricultural output through capital investment and increasing productivity. Price policies have been established largely to protect consumers and avoid inflation, although the use of producer incentive prices is now beginning to encourage increased output.

\section{Prospects for increasing food production}

The levels of food production per capita in various regions of the world since before the war are shown in Table 10.

A quick inspection of this table might suggest optimistic conclusions regarding the trend of per capita food production in recent years, since world per capita production is now well above the pre-war average. However, of the under-developed regions (Latin America, the Far East, the Near East and Africa), only in the Near East has per capita food production exceeded pre-war levels in the last three years.

What are the prospects for the under-developed areas? Region by region, the prospects over the next decade appear to be as follows:

\section{Near East}

This area as a whole now produces most of the food it consumes. Except in the case of the United Arab Republic and Libya, there are no substantial imports of food. Consumption per capita in terms of calories per day ranges from a little over 2000 in Iran to over 2700 in Israel, the latter being the only country with a fairly high quality of diet. In other countries, grain products-mainly wheat-are the mainstay of the diet. However, consumption of fruits and vegetables is relatively high in nearly all the countries.

It is probable that over the next decade agricultural production in the Near East will increase slightly faster than population growth.

The United Arab Republic faces a problem of limited land and water resources with which to grow food for a large and rapidly growing population. Food deficits will probably increase in the future.

\section{Latin America}

This region promises to remain a problem as regards food. With present population growth, it is doubtful whether agricultural output can keep pace 
with population growth. Consumption of food per caput varies widely among the countries-ranging from less than 1900 calories per day in Haiti to nearly 3000 calories per day in Uruguay. Argentina and Uruguay produce nearly all the food they consume and export substantial quantities. Most of the countries are trying to achieve greater self-sufficiency and had had considerable success, but unless more effort is devoted to agriculture, net food imports will probably increase over the next decade.

In common with other under-developed areas, Latin America is going through a period of rapid social change. The existing systems of land tenure may change in the years ahead, possibly causing a temporary disruption in food and agricultural production.

\section{Africa}

If the political problems of emerging statehood can be mastered quickly, the outlook for increased agricultural output per capita over the next decade is good. Consumption of calories per day ranges from over 2100 per capita in several countries to over 2600 per capita in others. No country has to rely on substantial imports of food, and a number produce food commodities for export.

The substantial land and water resources available for development will be a great asset if capital and technical assistance are extended.

\section{Far East}

This is the world's chief problem area as regards food. Once a net exporter of grain, it has become a large net importer since the second World War. It still produces large export surpluses of fats and oils, rubber, tin, and jute which earn a large proportion of its foreign exchange.

Although food production has increased since the immediate post-war period, output per capita is still below pre-war levels, strikingly so in several countries. Food consumption is considerably below the estimated requirements as indicated earlier.

All the countries in the region have begun long-range development plans for agriculture. A number of problems threaten the successful accomplishment of these plans: lack of sufficient capital for investment, high illiteracy rates, particularly among farmers, soils badly depleted in some areas by centuries of cultivation, and a constantly declining amount of arable land per capita.

The agricultural potential of the more sparsely populated rice bowl countries (Burma, Thailand, Laos, Cambodia, and South Viet-Nam) will probably languish for lack of demand for export. In Japan and Taiwan, where agriculture is very intensively practised, it seems doubtful whether 
yields will continue to increase as they have over the past decade. Other countries, such as the Philippines, Indonesia, Pakistan, Ceylon and India will be hard pressed to increase farm output faster than population.

More foreign financial and technical assistance will be necessary to achieve even modest increases in agricultural output per capita. Otherwise, foreign exchange earnings will be largely absorbed in payments for food imports. 


\section{Means of Increasing Output of Food}

There is no doubt that the potential definitely exists to increase substantially the world's food output. The possible means include bringing new land into production so that there can be a higher and better quality production on present agricultural lands; and massively supplementing agricultural production through synthesis of the basic food elements or by culture of lower plant forms such as yeast and algae.

\section{Additional lands}

Hardly more than a tenth of the total land area in the earth is now classed as arable. According to rough FAO estimates, about 1,400 million hectares, out of a total of 13,531 million, can be considered to be arable land, fallow land, or orchards according to existing definitions (Table 11). About twothirds of this total-somewhat less than 900 million hectares-are actually devoted to major crops; the rest being in temporary pasture, fallow, or minor crops. Another 2,600 million hectares (19 per cent) are in permanent meadows and pastures. The remainder of the land, amounting to about 70 per cent of the total, now produces little or no food.

The cultivated area of the world has increased significantly since the end of the second World War, as indicated in Table 12, which shows an increase of more than 80 million hectares in land under major crops between 1948-52 and 1958. How much more land could be brought under cultivation? Estimates vary widely, according to the assumptions made. These range from the position that only minor increases are possible to the far more optimistic position that almost three times the present area could be effectively utilized. Unfortunately, no comprehensive, detailed survey of the possibilities throughout the world has ever been attempted.

The largest areas of potentially cultivable land not now being cultivated are located in the tropics, especially in South and Central America and Africa and to a lesser extent in south-eastern Asia. Vast areas of land in the equatorial forest zones are either not used for agriculture or very sparsely cultivated by systems of temporary, shifting agriculture which support exceedingly small populations. In addition, there are huge areas of tropical savannahs now being used, at the most, as grazing ranges for cattle which supply very little food. In general, the fertility of these unused or little used lands 


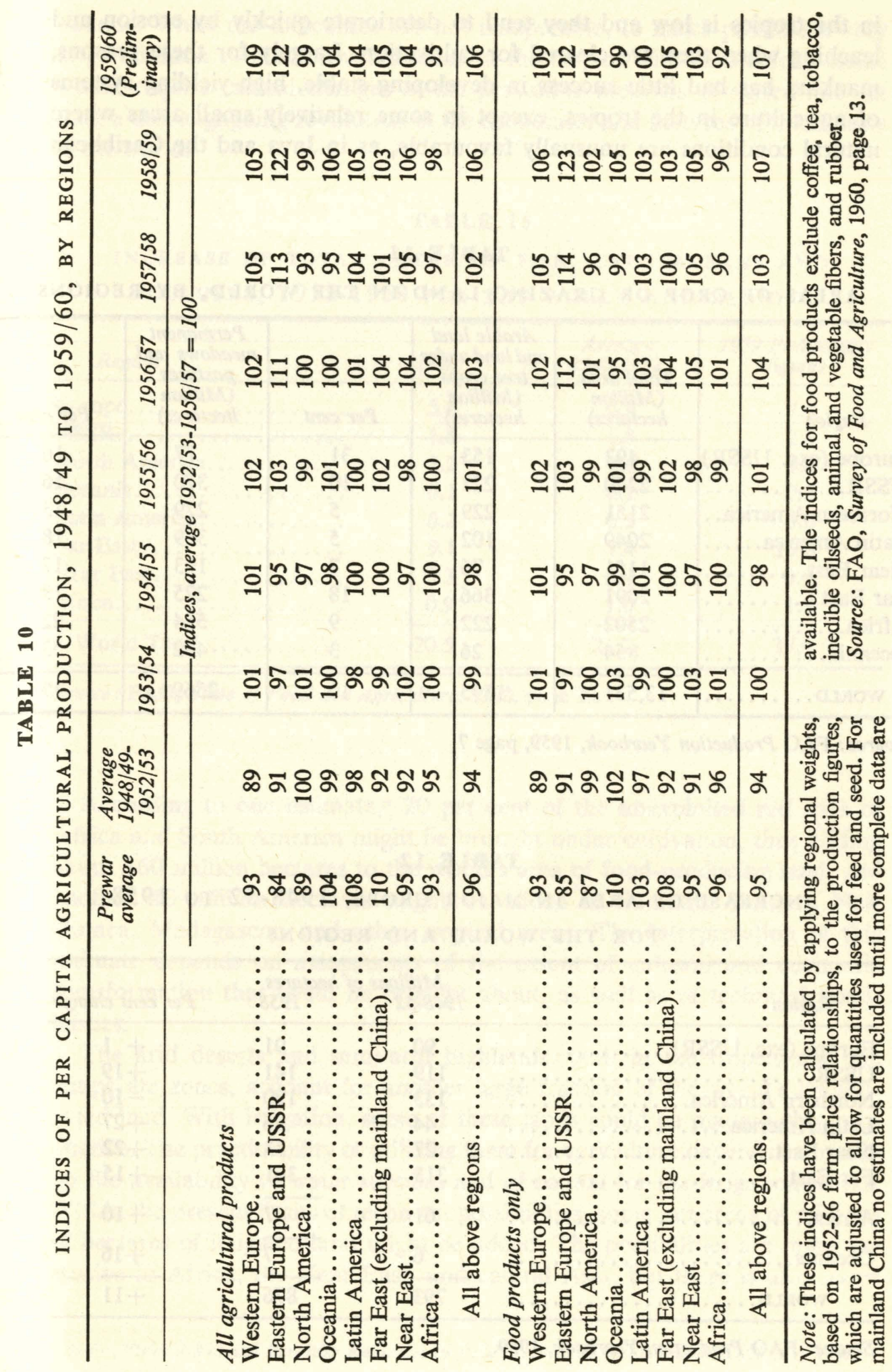


in the tropics is low and they tend to deteriorate quickly by erosion and leaching when they are cleared for cultivation. Largely for these reasons, mankind has had little success in developing stable, high-yielding systems of agriculture in the tropics, except in some relatively small areas where natural conditions are unusually favourable, as in Java and the Caribbean

\section{TABLE 11}

AREAS OF CROP OR GRAZING LAND IN THE WORLD, BY REGIONS

\begin{tabular}{|c|c|c|c|c|c|}
\hline Region & $\begin{array}{c}\text { Total area } \\
\text { (Million } \\
\text { hectares) }\end{array}$ & $\begin{array}{c}\text { Arable land } \\
\text { and land under } \\
\text { tree crops } \\
\text { (Million } \\
\text { hectares) }\end{array}$ & Per cent & $\begin{array}{c}\text { Permanent } \\
\text { meadows and } \\
\text { pastures } \\
\text { (Million } \\
\text { hectares) }\end{array}$ & Per cent \\
\hline Europe (exc. USSR) & 493 & 153 & 31 & 77 & 16 \\
\hline USSR............ & 2240 & 221 & 10 & 370 & 16 \\
\hline Northern America. . & 2151 & 229 & 5 & 279 & 13 \\
\hline Latin America...... & 2049 & 102 & 5 & 369 & 18 \\
\hline Near East......... & 1151 & 76 & 7 & 193 & 17 \\
\hline Far East........... & 2091 & 366 & 18 & 275 & 13 \\
\hline Africa............. & 2502 & 222 & 9 & 554 & 22 \\
\hline Oceania........... & 854 & 26 & 3 & 452 & 53 \\
\hline WORLD.......... & 13,531 & 1395 & 10 & 2569 & 19 \\
\hline
\end{tabular}

Source: FAO Production Yearbook, 1959, page 7.

TABLE 12

INCREASE OF AREA IN MAJOR CROPS, 1948-52 TO 1958 FOR THE WORLD AND REGIONS

\begin{tabular}{|c|c|c|c|}
\hline \multirow[b]{2}{*}{ Region } & \multicolumn{2}{|c|}{ Millions of hectares } & \multirow[b]{2}{*}{ Per cent change } \\
\hline & $1948-52$ & 1958 & \\
\hline Europe (exc. USSR) $\ldots \ldots \ldots \ldots \ldots \ldots$ & 90 & 91 & +1 \\
\hline 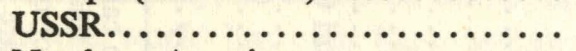 & 119 & 141 & +19 \\
\hline Northern America.............. & 133 & 120 & -10 \\
\hline Latin America................ & 44 & 56 & +27 \\
\hline Near East.................. & 27 & 33 & +22 \\
\hline Far East.................... & 313 & 361 & +15 \\
\hline 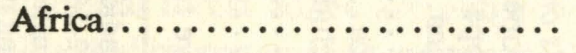 & 61 & 67 & +10 \\
\hline 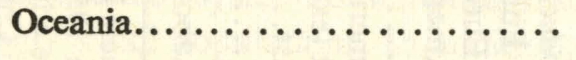 & 6 & 7 & +16 \\
\hline 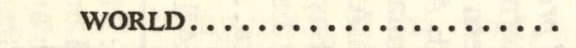 & 793 & 876 & +11 \\
\hline
\end{tabular}

Source: FAO Production Yearbook, 1959. 
Islands. While the difficulties are not insuperable, to make possible a very large addition to the cultivated areas in the tropics with satisfactory yields would require radical changes in the prevailing methods of agriculture-in fact, a thoroughgoing revolution in the economies and cultures of these parts of the world.

TABLE 13

INCREASE OF TOTAL CATCH OF FISH, CRUSTACEANS AND MOLLUSKS, 1938-1959 FOR THE WORLD AND REGIONS

\begin{tabular}{|c|c|c|c|}
\hline Region & 1938 & $\begin{array}{c}\text { Average } \\
1948-1952\end{array}$ & $\begin{array}{l}1959 \text { Preliminary } \\
\text { figures }\end{array}$ \\
\hline Europe.................. & 5.6 & 6.4 & 7.9 \\
\hline USSR................ & 1.5 & 1.8 & 2.8 \\
\hline North America........... & 3.2 & 3.6 & 4.0 \\
\hline Oceania................ & 0.1 & 0.1 & 0.1 \\
\hline Latin America. ........... & 0.2 & 0.5 & 3.0 \\
\hline Far East.............. & 9.1 & 7.4 & 15.5 \\
\hline Near East.............. & 0.3 & 0.4 & 0.4 \\
\hline Africa............... & 0.9 & 1.0 & 1.9 \\
\hline World Total........... & 20.5 & 21.2 & 35.6 \\
\hline
\end{tabular}

Source: FAO, State of Food and Agriculture, 1960, page 20.

According to one estimate, ${ }^{5} 20$ per cent of the unexploited red soils of Africa and South America might be brought under cultivation, thus adding about 360 million hectares to the world's area of food-producing land, and another 40 million hectares might be added in Sumatra, Borneo, New Guinea, Madagascar, and other tropical areas. The interpretation of this estimate depends on assessments of the extent of cultural and economic transformation that could be brought about, as well as of technical possibilities.

The arid deserts and semi-arid highlands, both in the tropics and the temperate zones, account for another large fraction of the world's uncultivated land. With irrigation, some of these lands could be made highly productive. The practicability of utilizing them for agriculture depends primarily on the availability of water supplies and of capital for the irrigation works. Within the present limits of technical possibilities, some hundreds of millions of hectares of irrigated land might be added. The possibilities are more extensive in Africa, the Near East, and central Asia, but there is also scope

\footnotetext{
"Salter, "World Soil and Fertilizer Resources in Relation to Food Needs", Science, 23 May 1947.
} 
for important additions, through irrigation, to the land resources of some of the more densely populated countries of southern and eastern Asia, including India and Pakistan, Ceylon, and China.

Although the execution of all irrigation projects now considered technically possible in various parts of the world would not increase the world's cultivable land area by a very large percentage, the contribution to foodproducing capacity would be proportionately greater, as high yields can generally be obtained from irrigated lands. Studies and experiments now under way may lead to a considerable extension of the technical possibilities in the future. However, "the limiting factor is not knowledge, as in the equatorial lands and the savannahs of the "new" continents, but finance". ${ }^{6}$

In the well-watered areas of the temperate zones, the two principal areas with large amounts of land not used for crops, although climate and other conditions are favourable, are southern Australia and the plains of southern Brazil and Uruguay. These lands are used mainly for grazing livestocks; the main obstacles to this conversion to crop land are land tenure conditions and cultural traditions. Similar possibilities for extending cultivation in the temperate zones of the Northern Hemisphere are much more narrowly limited. There the main reserves of potentially arable land are in the podzolsoil zones of the Northern USSR and Canada. It has been estimated that about ten per cent of these lands, or 300 million acres, might ultimately be brought under cultivation. ${ }^{?}$

\section{Increased production per hectare}

While expanding the area under cultivation will be important, it is evident that for many regions, particularly the densely settled ones, greater output per hectare of land will be necessary. There are great potentialities for increasing food production by application of improved practices to land already under cultivation.

A number of possibilities for increasing yields may be mentioned. ${ }^{8}$

\section{Improved crop varieties}

Through the application of modern genetics, within limits crop varieties can be bred to meet specific requirements, such as climatic adaptation, high yields, improved quality, and resistance to disease. While much plant breeding work is being done, some of it in under-developed areas, the wide diversity of soil and climatic conditions means that a multitude of varieties must be developed. Lack of trained personnel and facilities has hampered progress in

\footnotetext{
6 "Possibilities of Increasing the Supply of Food and Agricultural Products by Exploitation of New Areas and Increasing Yields", by W. H. Pawley and other experts of the FAO staff, in Proceedings of the World Population Conference, 1954, Volume V (United Nations Publication, Sales No. 1955. XIII.8). A revised version of this paper is being prepared for publication by the FAO in the near future as one of the basic studies for the Freedom-from-Hunger Campaign.
} 
this field. Nevertheless, very substantial gains in production could be achieved in under-developed countries by wider use of the improved varieties that are now known, in areas for which they are suited. Ignorance and the bonds of tradition are major hindrances, as well as the difficulties of obtaining the improved seeds and achieving other changes in agricultural techniques, on which satisfactory results from the cultivation of new varieties often depends.

\section{Building up soil fertility}

Tremendous increases in food production per hectare could be achieved by better soil management and more use of fertilizers in under-developed areas where the natural fertility of the soil is low or where it has been depleted by destructive methods of cultivation. Efficient crop rotation schemes involving the use of legumes and grasses to add humus and nitrogen to the soil are of great importance in this connexion, as well as the use of compost and animal manure in mixed-farming systems. There has been little or no development of such agricultural methods in enormous areas of the underdeveloped world. Chemical fertilizers also could play an extremely important part in increasing production per hectare. In India, for instance, it has been estimated that a moderate dressing of about 30 kilogrammes of nitrogen per hectare would bring an increase of more than 10 million tons in the annual production of rice. According to FAO experts, food production could be increased by at least 50 per cent in almost all countries of the world, and it could be doubled in many areas, simply by better and more intensive use of fertilizers, manures, and legumes. ${ }^{9}$ If chemical fertilizers are to be used widely, however, there must be substantial facilities for producing them and the farmers must be able to afford to buy them. Full benefits are only gained from them by extensive soil testing, demonstration and advisory services.

\section{Combating pests and diseases}

Great quantities of food are destroyed each year by pests and diseases which attack either the growing crops and livestock or the food products as they are processed, stored, and transported. It is believed that these losses are equivalent to the annual production of many millions of hectares. Most of them could be prevented at relatively small cost by applying the scientific knowledge which is now available. The gap between what is done and what could be done in this respect has never been wider than it is today, when new weapons for control of pests and diseases that have been produced

7 Salter, op. cit.

8 Leonard, "World Population in Relation to Potential Food Supply", Scientific Monthly, Sept. 1957;

Pawley, and others, op. cit.

9 Pawley and others, op. cit. 
by scientific research in recent years, for example, fungicides, antibiotics, insecticides, and weed killers are far more efficient than any known in the past. It is scarcely economical, however, to spend much on disease and pest control measures where the yields are very low because of other factors. As yields are improved by other means, plant and livestock protection can play an increasingly important role in food production. More and better refrigeration and storage facilities, where these are lacking or inadequate, can also do much to reduce food losses.

\section{Agricultural implements and machinery}

Mechanical equipment has revolutionized farming in some parts of the world, principally North America, Europe and the USSR, and Australia. While it has made possible vastly increased output per worker, its contribution to increasing output per hectare has been much more modest. In many of the under-developed countries, the advantage that could be obtained from increased use of agricultural machinery under present conditions would be limited in view of the existing surpluses of agricultural labour, as well as the difficulties of obtaining fuel, servicing, and spare parts. More important gains in production per hectare, and also in facilitating the extension of cultivated areas, could be won by improvements in simple tools, such as the substitution of a metal hoe for a wooden digging stick, equipping a wooden ploughshare with a steel point, and using a wheeled cart to transport materials and produce which are now being carried laboriously on a man's back.

\section{Greater production of livestock}

Domestic animals and fowl are an important source of food in the form of meat, dairy products, and eggs. Better feeding and breeding methods artificial insemination, and disease and pest control can make possible higher production of these products. Animals are able to convert food resources unsuitable for direct use by man. They supply nutrients that are deficient in the high cereal diets on which much of the world population subsists. However, in several regions of the world, notably India and parts of Africa, there would be little advantage in increasing livestocks in present circumstances; religious and cultural traditions lead to the existence of excessive numbers of poor quality livestock which are competitors with human beings for food rather than being a primary source of food.

\section{Combination of practices}

While important gains in agricultural production can often be made through application of one or two simple measures, continued progress in increasing production depends on combining such practices as improved 
seeds, fertilizers, soil and water management, and pest control into a balanced system of husbandry.

\section{Other sources of food}

Fish is an important source of food in many countries, and contributes about 10 per cent of the total animal protein in the current world food supply. It is potentially important particularly for protein-short regions. Cultivation of fish has long been practised in ponds or paddies in China and Japan where it is an important source of animal protein, and the practice has spread to several other countries in the Far East. The world fishery catch before World War II was approximately 20 million tons. It barely recovered in the postwar period, and now stands at about 36 million tons (See table 13). Sizable fisheries are being exploited off Africa and South America.

In recent years a number of altogether untouched sources of food have been discussed as possibilities for expanding world food output. Yeasts and algae with high protein and vitamin content can be used to convert wastes into food and to produce large quantities of material per hectare. At present, these processes may not be economically feasible and their products may not be accepted.

A number of vitamins are now produced synthetically and cheaply. Concentrated foodstuffs can also be manufactured as diet supplements on a mass scale.

\section{Summary of the problem of food production}

To sum up, it is clear that the earth's physical resources and man's present technical knowledge are sufficient to multiply the world's production of food many times. But the existence of resources and technical knowledge is not enough in itself to bring about the increase of production which the world desperately needs at present and the further increases which will be needed in the future to feed the growing population according to a satisfactory standard. To be effective, knowledge must be applied in developing resources and increasing productivity. The magnitude of the obstacles that must be overcome in bringing present knowledge into full play throughout the world cannot be over-emphasized.

Farmers must be given the incentive to produce larger quantities of food. Reliable markets, good prices, and facilities for transport, storage, handling, and processing must be developed. Channels of supply for fertilizers, pesticides, and improved seeds must be expanded. Institutional reforms affecting such matters as credit and tenure are often necessary. Advisory services must be supplied to spread the techniques that have proved successful and research programmes to develop successful practices are necessary. Capital must be obtained and invested, not only in the development of land resources 
and agricultural equipment, but also in the non-agricultural sector of the economy-in industrial plants, railroads, storage facilities, laboratories, and so on-and also in schools, hospitals, and the other essential facilities for social and economic progress.

So the problem of mouths and food is seen as an inseparable part of the whole, vast problem of economic, social, and cultural development of the world's under-developed regions. There is no sure or simple answer. On the relation of population growth to these problems, a survey published by the United Nations Economic Commission for Asia and the Far East ${ }^{10}$ stated that "the faster the population grows, the more difficult it be to assure the necessary investment funds for an equivalent increase in agriculture production, and capital is one of the main limiting factors to economic growth in Asian countries. Furthermore, the cumulative nature of changes in population size following from a continued high rate of fertility will increase pressure on effective food supplies unless there is a considerably greater acceleration in such supplies than foreseeable ..."

"If Asian agriculture adopted the modernized techniques used in some other parts of the world, food production in most of the countries could probably be made to keep pace with this upsurge in demand for food. In addition, research and technological advancement might make it possible to cultivate land which has been hitherto considered uncultivable."

The solution of the world's food crisis appears to be a matter of having not only the power but also the will to solve it. The total application of existing technologies would unquestionably provide enough and for all. But how can this knowledge be put to work? Where will the capital come from to set up this world food production plant? What might be done to redistribute the existing food? At present, 400 million human beings in the western industrial nations consume as much protein as 1,300 million of their fellow men in Asia. A great effort must be made to equalize these disparities.

${ }^{10}$ Economic Bulletin for Asia and the Far East, June 1959. 


\section{The Issue of Population Policy}

In terms of simple arithmetic, it seems evident that the problem of achieving the needed increases in food production during the next decades would be made easier, and the risk of failures would be diminished, if the population were to increase less than is indicated by the projections of present trends for the economically less developed regions of the world. Actually, the mathematics of the problem are not so simple; it is not just a question of addition of a larger or smaller number of consumers to share a certain quantity of food, for people are producers as well as consumers. While population growth adds to requirements, it also contributes, through increasing manpower, to the possibilities of producing food and other goods. It is necessary to consider the relative effects on requirements and productive capacity in order to get a correct expression of the equation of food and mouths, and the form of the equation is not the same in regimes where the economic circumstances differ. Still, when these complexities are taken into account, it appears that population growth at the rates now observed in most of the under-developed countries is a major hindrance in solving the problems of food supply and of general economic and social development.

With few exceptions, the experts who have studied this question agree that the outlook would be far more favourable if the present rates of population increase in the under-developed countries could be slowed down by moderation of birth rates. In fact, some experts hold that unless the growth of population becomes slower in the near future, there is little hope of improving the conditions of life in many of these countries or even to hold the present low levels of living may prove to be difficult.

In the case of India, it is clear that the present rate of population growth is a very serious impediment to the country's economic development and the solution of its food problem. Coale and Hoover ${ }^{11}$ have worked out a series of three models to show how the conditions might appear in 1986 with different assumptions for the trend of human fertility in India up to that time. In each model it is assumed that the death rate will fall by more than 40 per cent by 1986 .

Model I assumes that fertility begins to decline immediately and continues down to half its present level by 1981 . 
Model II assumes no change in fertility until 1966 , and then a decline so sharp that fertility is cut in half by 1981 .

Model III assumes that fertility will remain at the present level until 1986.

The analysis includes such items as national income available for investment in productive facilities; needs for housing, social services, schooling, and other welfare expenditures; and the proportion of labour force in the total population. It does not take into account certain intangible gains such as increased vigour of the population owing to better living conditions.

Under Model I, with an immediate decline in the birth rate, the population will grow to 589 million by 1986 . Since there is no immediate prospect of an effective lowering of the Indian birth rate, this model is mainly of theoretical interest. It does serve to stress how important the level of fertility is to a nation which wants to achieve an economic break-through. If India's birth rate had miraculously started to decline in 1959 , her economy and the welfare of her people would be far more advanced in 1986 than under either of the other alternatives.

Under existing conditions, there is a definite possibility that Model II might be achieved. If the birth rate should begin to drop sharply after 1966, the population would grow to 634 million by 1986 .

Under Model III, with the birth rate remaining at its present level, a population of 775 million is the prospect for 1986 . That is nearly double the present population.

Coale and Hoover find that continuing high fertility would present a major barrier to an economic breakthrough. The proportion of children under 15 in 1986 would be so high ( 42 per cent, compared with 30 per cent for the low projection) as to constitute a decisive handicap to economic development.

By that time, only 10.1 per cent of India's national income would be available for productive investment. With almost twice as many people, each year a larger proportion of capital would be diverted for essential social services, such as health and education and for non-productive investment, such as housing. In contrast, under the low-fertility pattern of Model I, 14.7 per cent of the national income would be available for productive investment.

The difference between 10.1 per cent and 14.7 per cent of the national income may not seem impressive. But for a nation struggling to emerge from a marginal agrarian culture, it might well mean the difference between victory and defeat in the battle for economic self-sufficiency. The higher percentage would be adequate to provide a gradual improvement of living levels. Under Model III, a decline not only of the per capita gross national product but of the total national product would be expected.

The problem is not the same where the density of population is lower and there are large reserves of unused or little used land suitable for agriculture, as in many countries of Latin America and Africa. But it has been pointed 
out that even in such circumstances, excessively rapid growth of population is a major hindrance to economic development. The report of a recent United Nations seminar on population problems in Latin America makes the following observations on this score: ${ }^{12}$

"Of course for each new mouth there is also a pair of hands. But the mouth has to be fed now; the hands become useful only some years later. In several Latin American countries as much as 40 per cent of the population is under the age of fifteen. At the same time, Governments must find productive jobs for a rapidly growing and sometimes poorly trained labour force, a task which entails demands on scarce capital resources which would not be made by a population growing less rapidly. From each of these points of view, present rates of population growth are a real handicap to economic development. “... The majority of the countries in this region are generally believed to be under-populated in the sense that if they had more people, suitably distributed within their territory, they could make more effective use of resources which are now idle, and could benefit from certain economies in the scale of production and distribution of goods and services ... On the other hand, it seems to have been made clear that nearly all countries of the region are suffering from a considerable handicap in their efforts towards economic development because of the rapid rates at which their populations are growing. Those which are under-populated naturally have less reason to be concerned about this matter than the others, but in their case, too, it seems evident that in spite of the advantages which in the long run might accrue to them from a larger population, their economic progress would be more satisfactory if they could arrive at those larger numbers at a more leisurely pace."

These considerations lend force and urgency to the demands for policies in favour of birth regulation which are being pressed upon governments in various parts of the world and upon the United Nations. But the issue of population policy and birth regulation is not purely one of economics. It also involves questions of cultural ideals, moral principles, and social and political philosophy which are seen in different lights by the people and the governments of different countries. Some groups object in principle to birth control in general or to certain forms of it; others hold that the decision to practise it or not should be left strictly to the people without any governmental interference or pressure.

The councils of the United Nations, confronted with the sharp differences in view on this question, have taken the position that it must be left to each national government to decide its own policy. The United Nations Population Commission declared in the report to the Economic and Social Council on its eleventh session (1961): ${ }^{13}$

"It is the responsibility of each Government to decide its own policies and devise its own programmes of action for dealing with the problems of popula-

\footnotetext{
12 Seminar on Evaluation and Utilization of Population Census Data in Latin America (ST/TAO/ SER.C/46; E/CN.9/CONF.1/1/Rev.1). United Nations, New York, 1960. p. 37.

13 Population Commission, Report of the Eleventh Session (7-17 February 1961). Economic and Social Council, Official Records, Thirty-first Session, Supplement No. 3.
} 
tion and economic and social development. In particular, each Government must decide for itself whether or not any measures should be taken for the purpose of modifying the trends of population as an aid to the solution of these problems, taking into account the work of the Population Commission. On the other hand, it is in the interest of the United Nations that decisions on national policies should be taken, and national action programmes should be planned, in the light of knowledge of the relevant facts, and that the programmes should be adequate to assure satisfactory economic and social progress. Among the circumstances which must be considered are the relevant features of national culture and ideals as well as the trend of population, the physical resources and other economic circumstances of each country. It is appropriate that the United Nations should encourage and assist the Governments, especially of the less developed countries, in obtaining basic data and carrying out essential studies of the demographic aspects, as well as other aspects, of their economic and social development problems. It is also considered appropriate for the United Nations to give technical assistance, as requested by Governments, for national projects of research, experimentation and action for dealing with problems of population."

It would appear from the above that the United Nations neither encourages nor discourages adoption by Governments of any particular population policy, but stands ready upon request to give technical assistance to Governments for the purpose of making effective whatever policies they may adopt.

In four of the most populous Asian countries-India, Pakistan, China (mainland) and Japan-the Governments have sponsored various kinds of measures aimed at encouraging limitation of births and moderating the rate of population growth, as an aid to economic and social advancement.

In India, a programme introduced with the first five-year plan in 1951 provided advice and assistance on family planning as part of the services in hospitals and health centres. Attention was also given to training and research. In the second five-year plan, this programme was intensified, and the funds allocated have been increased almost eightfold. The third five-year plan provides for further expansion in the programme. However, neither this programme nor a similar one in Pakistan appears as yet to have brought about any great reduction in births.

A technical discussion of the problems involved in making a birth-control programme effective in a country such as India or Pakistan is outside the scope of this report. Suffice it to say that the problem is not solely one of techniques and supplies of materials; it is also a problem of communications and education, which takes on enormous dimensions in a large and populous country where the vast majority of the population is illiterate, povertystricken, and isolated in great numbers of rural villages spread out over vast areas. On the technical side, experiments that are now under way-including some advanced testing on animals and clinical trials on humans as well as laboratory work-may soon yield methods of fertility control that will be 
simpler, less expensive, and better suited to large-scale use in underdeveloped countries than the methods now employed. But the means, no matter how well they may be adapted to local living conditions and mores, are less important than the will, based on understanding of the consequences of an excessive number of births for the welfare of the family, the community and the nation.

In mainland China, the programme of family planning was launched in 1955. The results of the 1953 population census had just been published, and the effect of the rapid population increase on the problems of industrialization and economic development was realized.

The programme, first on a modest scale, but considerably intensified for a time subsequently, made guidance in family planning an important part of the activities of hospitals, and child and maternity centres. There is no reliable information regarding the effects of this programme on the birth rate.

In Japan, the Government, before and during the Second World War, enforced a pro-natalist policy. But public interest in family planning rose sharply soon after the close of the War probably owing to economic pressure upon the families. Abortions flourished; in 1948, abortions and sterilization were legalized on certain specified grounds; in 1952 further liberalization of the abortion law took place. Abortions are estimated to be approximately equally in number to live births, but the frequency of abortions may be on the decline as a result of the vigorous programme for promoting dissemination of contraceptive information.

The birth rate in Japan dropped from 30.1 per 1,000 population in $1945-49$ to only 17.2 per 1,000 in 1957 . As the death rate dropped during this period from 17 to 8 per 1,000 , the net result was to bring the annual rate of natural increase of the population down from 1.3 per cent to 0.9 per cent. Japan's birth rate at present is as low as or lower than the rates of most European countries and considerably below the present birth rates in the USSR, the United States and Canada. In Japan's case, the movement to limit births was greatly facilitated by the comparatively high degree of industrialization and economic development of the country, and the high level of education of the people, in comparison with other countries in Asia and the Far East.

In a number of other areas, including Ceylon, China (Taiwan), Hong Kong and Singapore, family planning activities are supported by the Government although the Government itself does not take a lead in promoting such measures. In countries such as the Federation of Malaya and Thailand, family planning activities are supported by private organizations only, with no direct assistance from the Government.

In those parts of the world where there is strong opposition to birth-control programmes on moral, religious, or other grounds, the solution of the population problems is all the more difficult. The report of the United Nations 
seminar on population problems in Latin America, mentioned earlier, contains the following remark on this subject:

"Most Governments in Latin America would be very hesitant to adopt a policy aimed at encouraging family planning. For them, if they feel any need to slow down population growth, the appropriate measures of policy will be less direct-they might be concerned, for instance, with possible means of instilling into the minds of the poorer and less educated classes of the people a keener sense of responsibility and prudence in regard to marriage and the birth of children, which would be consistent with their religious ideals and the highest values of their culture."

In spite of all the difficulties, it may prove possible within a decade or two to achieve with determined efforts, appreciable reductions of birth rates in the countries where national policies having this aim have been adopted, or where they may be adopted in the near future. But it scarcely seems realistic in view of all the circumstances to expect a radical reduction of births in the under-developed countries generally during the next ten or twenty years. Meanwhile, the population of most of these countries can be expected to go on growing rapidly-quite possibly even more rapidly than it is growing at present. Thus it is absolutely imperative to find adequate solutions for the problems of increasing food production sufficiently during the decades ahead, especially in those countries where the present standards of food consumption are lowest and where the largest increases of population are in store.

\section{Prospects of increasing food production}

Experts are convinced that technical knowledge exists to meet the world's present food shortages and to take care of the needs that will result from population growth for some time to come. Similarly, there is enough technical knowledge of the means of controlling births to bring about a decided moderation of the rate of population growth whenever the Governments-and more important, the people-have the will to do so.

If everything possible were done to bring the existing technical knowledge of food production methods to bear fully throughout the world-including, among other things, large-scale programmes for training key personnel, vigorous and imaginative attacks on ignorance and traditional inertia, and massive mobilization of capital on a worldwide scale for investments in agricultural and industrial development of the under-developed regions-the Freedom from Hunger Campaign might achieve its great objective over the course of some decades. But neither the present programmes nor the efforts to implement them are adequate.

In India, for instance, the current large expenditure on agricultural research and development has served to increase food production by about 3 per cent a year, but an 8.2 per cent annual increase is necessary to meet the 1965-66 targets for adequate production. ${ }^{14}$

14 Report on India's Food Crisis and Steps to Meet It. Government of India. April, 1959. p. 11. 
With reference to the countries of Asia and the Far East, the ECAFE report previously quoted ${ }^{15}$ puts the problem in these terms:

“. . . If Asian agriculture adopted the modernized techniques used in some parts of the world, food production in most of the countries could probably be made to keep pace with this upsurge in demand for food. In addition, research and technological advance may make it possible to cultivate land which has been hitherto considered uncultivable ...

On the assumption that average land productivity in Asia could be raised to Japanese levels, that calorie supplies were increased to 2,500 per person per day and the present low-protein type of diet maintained, many countries could still support a population two or three times as big as their present population. Assumptions, on the other hand, of calorie supplies at the same level as in, say, the western European countries and a diet of a high animal protein content would imply that many countries, even at the very high Japanese levels of land productivity, could support fewer people than their present populations ...

All these calculations indicate the need to bring the present divergent trends in mortality and fertility into a closer balance within a not very distant future."

In addition to the programmes for increasing agricultural efficiency through fertilizers, seeds, mechanization and better techniques, there is the technical possibility, although at somewhat higher costs, of producing foods from sources not now exploited: algae, yeasts, fish meals, and hydroponics, and by the use of extractive methods for converting plants directly into proteins and oils instead of raising secondary sources of nutrients such as fish and animals. However, the difficulties must not be underestimated-"the mere fact that it is theoretically possible to increase food production should not blind us to the magnitude of the task. It is immense. Agriculture involves more of the people of the world than any other productive activity. To change its procedures, we must change attitudes." 16

By 1970, the population of the earth will be increased by over half a billion. Most of this increase can be expected to occur in the under-developed, food-short regions of Asia, Africa and Latin America, where population growth rates in some countries are now higher than any that have been known in the history of the human race.

Time is too precious to be wasted in futile arguments over what steps should be taken first to deal with the problem of population and food supply. Nothing less than an "all out" attack on all major aspects of the problem can bring success. To banish hunger and achieve a minimal diet for all people in the face of rapid population growth will at best take time. To check population growth in those countries where such is the desire of the people and their governments will also take time. And time is of the essence.

\footnotetext{
${ }^{15}$ Economic Bulletin for Asia and the Far East, June 1959.

16 Brown, Harrison; Bonner, James and Weir, John. The Next Hundred Years, The Viking Press. New York, 1957, p. 82.
} 


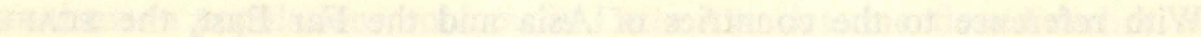

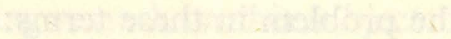

Q

Whin

$6+2028$

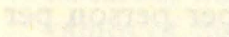

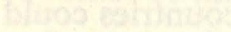

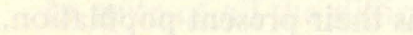

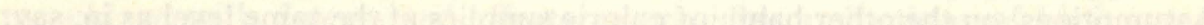

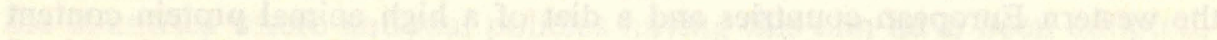

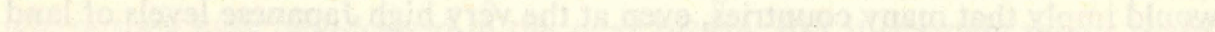

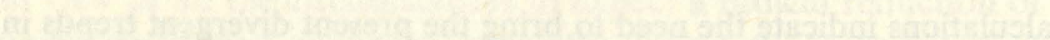
-

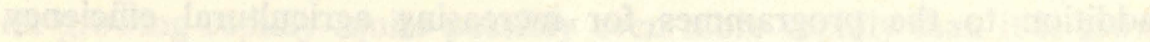

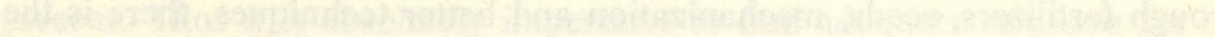

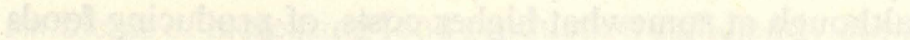

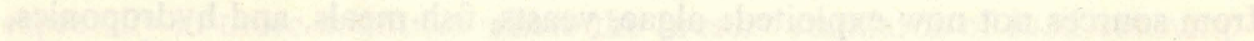

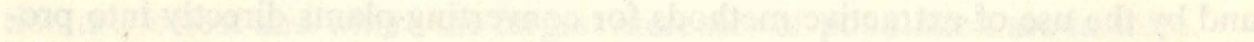

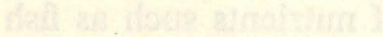

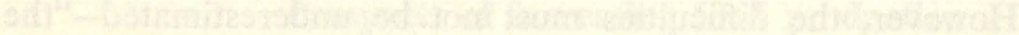

binat

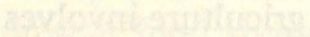

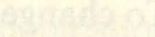

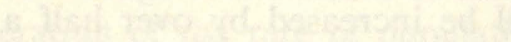

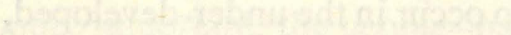

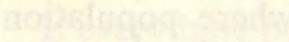





\section{AFRICA}

CAMEROUN: LIBRAIRIE DU PEUPLE AFRICAIN La Gérante, B.P. 1197, Yaoundé. ETHIOPIA: INTERNATIONAL PRESS AGENCY
P. O. BOX 120. Addis Ababa.

GHANA: UNIVERSITY BOOKSHOP

University College of Ghana, Legon, Accra.

MOROCCO: CENTRE DE DIFFUSION DOCUMEN

TAIRE DU B.E.P.I., 8, rue Michaux-Bellaire, Rabat. SOUTH AFRICA: VAN SCHAIK'S BOOK.

STORE (PTY) LTD.

Church Street, Box 724, Pretoria.

UNITED ARAB REPUBLIC: LIBRAIRIE

"LA RENAISSANCE D'EGYPTE"

9 Sh. Adly Pasha, Cairo.

\section{ASIA}

BURMA: CURATOR, GOVT. BOOK DEPOT

Rangoon.

CAMBODIA: ENTREPRISE KHMERE DE LIBRAIRIE

Imprimerie \& Papeterie Sarl, PhnOM Penh.

CEYLON: LAKE HOUSE BOOKSHOP

Assoc. Newspapers of Ceylon, P. O. Box 244.

Colombo:

CHINA:

THE WORLD BOOK COMPANY, LTD.

99 Chung King Road, 1st Section, Taipeh,

Taiwan.

THE COMMERCIAL PRESS, LTD.

211 Honan Road, Shanghai.

HONG KONG: THE SWINDON BOOK COMPANY

25 Nathan Road, Kowloon.

INDIA:

ORIENT LONGMANS

Calcutta, Bombay, Madras, New Delhi

and Hyderabad.

OXFORD BOOK \& STATIONERY COMPANY

New Delhi and Calcutta.

P. VARADACHARY \& COMPANY

Madras.

INDONESIA: PEMBANGUNAN, LTD.

Gunung Sahari 84, Djakarta.

JAPAN: MARUZEN COMPANY, LTD.

6 Tori-Nichome, Nihonbashi, Tokyo.

KOREA, REPUBLIC OF: EUL.YOO PUBLISH

ING CO., LTD.

5, 2.KA, Chongno, Seoul.

PAKISTAN:

THE PAKISTAN CO.OPERATIVE BOOK SOCIETY

Dacca, East Pakistan.

PUBLISHERS UNITED, LTD.

Lahore.

THOMAS \& THOMAS

Karachi.

PHILIPPINES: ALEMAR'S BOOK STORE

769 Rizal Avenue, Manila.

SINGAPORE: THE CITY BOOK STORE, LTD.

Collyer Quay.

THAILAND: PRAMUAN MIT, LTD.

55 Chakrawat Road, Wat Tuk, Bangkok.

VIET-NAM, REPUBLIC OF: LIBRAIRIE-PAPETERIE

185, rue Tu.do, B.P. 283, Saigon.

\section{EUROPE}

AUSTRIA:

GEROLD \& COMPANY
Graben 31, Wien, 1.

B. WÜLLERSTORFF

Markus Sittikusstrasse 10, Salzburg.
BELGIUM: AGENCE ET MESSAGERIES

DE LA PRESSE, S. A.

CZECHOSLOVAKIA: ČESKOSLOVENSKÝ

SPISOVATEL

Národní Trída 9, Praha 1.

DENMARK: EJNAR MUNKSGAARD, LTD.

Nørregade 6, København, $\mathrm{K}$.

FINLAND: AKATEEMINEN KIRJAKAUPPA

2 Keskuskatu, Helsinki.

FRANCE: ÉDITIONS A. PÉDONE

13, rue Soufflot, Paris (Ve).

GERMANY, FEDERAL REPUBLIC OF:

R. EISENSCHMIDT

Schwanthaler Str. 59, Frankfurt/Main.

ELWERT UND MEURER

Hauptstrasse 101. Berlin-Schöneberg

ALEXANDER HORN

Spiegelgasse 9, Wiesbaden.

W. E. SAARBACH

Gertrudenstrasse 30 , Köln (1)

GREECE: KAUFFMANN BOOKSHOP

28 Stadion Street, Athens.

ICELAND: BÓKAVERZLUN SIGFÚSAR

EYMUNDSSONAR H. F.

Austurstraeti 18, Reykjavik.

IRELAND: STATIONERY OFFICE

Dublin.

ITALY: LIBRERIA COMMISSIONARIA

SANSONI,

Via Gino Capponi 26, Firenze,

LUXEMBOURG: LIBRAIRIE J. TRAUSCH. SCHUMMER

Place du Théâtre, Luxembourg.

NETHERLANDS: N.V. MARTINUS NIJHOFF Lange Voorhout 9 , 's.Gravenhage.

NORWAY: JOHAN GRUNDT TANUM

Karl Johansgate, 41, Oslo.

PORTUGAL: LIVRARIA RODRIGUES Y CIA.

186 Rua Aurea, Lisboa.

SPAIN:

LIBRERIA BOSCH

11 Ronda Universidad, Barcelona.

LIBRERIA MUNDI.PRENSA

Castello 37, Madrid.

SWEDEN: C. E. FRITZE'S KUNGL. HOVBOK

HANDEL A.B

Fredsgatan 2, Stockholm.

SWITZERLAND:

LIBRAIRIE PAYOT, S. A.

Lausanne, Genève.

HANS RAUNHARDT

Kirchgasse 17, Zürich 1 .

TURKEY: LIBRAIRIE HACHETTE

469 Istiklal Caddesi, Beyoglu, Istanbul.

UNION OF SOVIET SOCIALIST REPUBLICS

MEZHDUNARODNAYA KNYIGA

Smolenskaya Ploshchad, Moskva.

UNITED KINGDOM: H. M. STATIONERY

OFFICE,

P. O. Box 569, London, S.E.1

(and HMSO branches in Belfast, Birmingham,

Bristol, Cardiff, Edinburgh, Manchester).

YUGOSLAVIA:

CANKARJEVA ZALOŽBA

Ljubljana, Slovenia.

DRZAVNO PREDUZEĆE

Jugoslovenska Knjiga, Terazije 27/11

Beograd.

PROSVJETA

5. Trg Bratstva i Jedinstva, Zagreb.

PROSVETA PUBLISHING HOUSE

Import-Export Division, P. O. Box 559

Terazije $16 / 1$. Beograd.

\section{LATIN AMERICA}

ARGENTINA: EDITORIAL SUDAMERICANA, S. A. Alsina 500, Buenos Aires.

BOLIVIA: LIBRERIA SELECCIONES

Casilla 972, La Paz.

BRAZIL: LIVRARIA AGIR

Rua Mexico 98-B, Caixa Postal 3291.

CHILE:

EDITORIAL DEL PACIFICO

Ahumada 57, Santiago.

LIBRERIA IVENS

Casilla 205, Santiago.

COLOMBIA: LIBRERIA BUCHHOLZ

Av. Jiménez de Quesada 8.40, Bogotá.

COSTA RICA: IMPRENTA Y LIBRERIA TREJOS

Apartado 1313, San José.

CUBA: LA CASA BELGA

O'Reilly 455, La Habana.

DOMINICAN REPUBLIC: LIBRERIA DOMINICANA

Mercedes 49, Santo Domingo.

ECUADOR: LIBRERIA CIENTIFICA

EL SALVADOR: MANUEL NAVAS Y CIA.

GUATEMALA: SOCIEDAD ECONOMICA.

6a. Av. 14-33, Guatemala City.

HAITI: LIBRAIRIE "À LA CARAVELLE"

Port-au-Prince.

HONDURAS: LIBRERIA PANAMERICANA

Tegucigalpa.

MEXICO: EDITORIAL HERMES, S. A.

Ignacio Mariscal 41, México, D. F.

PANAMA: JOSE MENENDEZ

Agencia Internacional de Publicaciones.

21.58, Panamá.

PARAGUAY: AGENCIA DE LIBRERIAS

39.43, Asunción.

PERU: LIBRERIA INTERNACIONAL

DEL PERU, S. A. Casilla 1417, Lima.

URUGUAY: REPRESENTACION DE EDITORIALES.

PROF. H. D'ELIA

Plaza Cagancha $1342,1^{\circ}$ piso, Montevideo.

VENEZUELA: LIBRERIA DEL ESTE,

Av. Miranda, No. 52, Edf. Galipán, Caracas.

\section{MIDDLE EAST}

IRAQ: MACKENZIE'S BOOKSHOP

Baghdad.

ISRAEL: BLUMSTEIN'S BOOKSTORES

35 Allenby Rd. and 48 Nachlat Benjamin St.

JORDAN: JOSEPH I. BAHOUS \& $C O$.

Dar-ul-Kutub, Box 66, Amman.

LEBANON: KHAYAT'S COLLEGE BOOK

92.94, rue Bliss, Beirut.

\section{NORTH AMERICA}

CANADA: THE QUEEN'S PRINTER

Ottawa, Ontario.

UNITED STATES OF AMERICA: SALES SECTION.

UNITED NATIONS, NEW YOrK.

\section{OCEANIA}

AUSTRALIA: MELBOURNE UNIVERSITY PRESS 369 Lonsdale Street, Melbourne, C.1.

NEW ZEALAND: UNITED NATIONS ASSOCIATION OF NEW ZEALAND, C.P.O. 1011. Wellington.

[62E 1]

Orders and inquiries from countries where sales agencies have not yet been established may be sent to: Sales Section, United Nations, New York. U.S.A., or to Sales Section. United Nations, Palais des Nations. Geneva, Switzerland. 